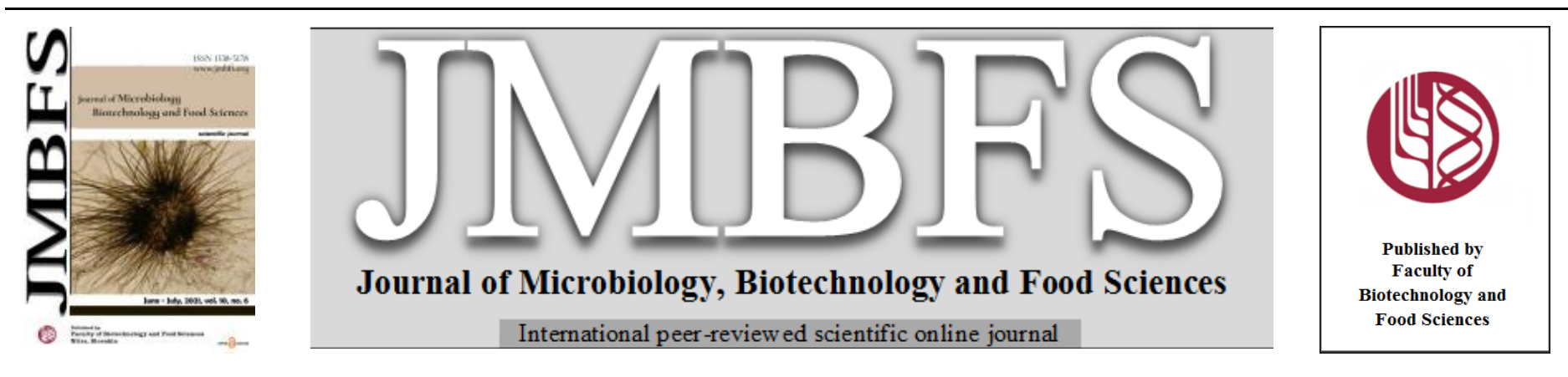

\title{
BIONANOTECHNOLOGIES: SYNTHESIS OF METALS' NANOPARTICLES WITH USING PLANTS AND THEIR APPLICATIONS IN THE FOOD INDUSTRY: A REVIEW
}

\author{
Svitlana Tsekhmistrenkol, Vladimir Bityutskyy, Oksana Tsekhmistrenkol, Serhii Merzlo ${ }^{1}$, Natalia Tymoshok ${ }^{2}$, Alexander \\ Melnichenko ${ }^{1}$, Svitlana Polishcuk ${ }^{1}$, Alexander Demchenko ${ }^{2}$, Igor Yakymenko ${ }^{3}$
}

\author{
Address(es): \\ ${ }^{1}$ Bila Tserkva National Agrarian University, Department of Biotechnology, 8/1, Soborna Sq., 09117 Bila Tserkva, Ukraine, +38(068) 0344848. \\ ${ }^{2}$ Zabolotny Institute of Microbiology and Virology of NAS of Ukraine, Kyiv. \\ ${ }^{3}$ National University of Food Technologies, Kyiv, Ukraine.
}

*Corresponding author: Svetlana.tsehmistrenko@gmail.com

https://doi.org/10.15414/jmbfs.1513

\section{ARTICLE INFO}

Received 3. 4. 2019

Revised 17. 5. 2019

Accepted 28. 5. 2021

Published 1. 6. 2021

Regular article OPEN $\partial_{\text {AcCESS }}$

\begin{abstract}
The basic principles of bionanotechnology and modern "green" chemistry are considered. The methods of synthesizing nanoparticles such as "top-down" and "bottom-up" are analyzed. The advantages of "green" synthesis of nanoparticles from plant raw materials with unique properties and a wide range of applications are presented. There are systematized factors that influence the biosynthesis of nanoparticles: the nature of the plant extract, the $\mathrm{pH}$ of the reaction mixture, the temperature of the incubation, the reaction time, the concentration and the electrochemical potential of the metal ion. The prospect of using nanotechnological approaches for the whole chain of agricultural production, as well as in the food industry, which will promote the creation of new nanomaterials, is shown. Nanotechnologies are successfully used to ensure the quality of food, enrichment of food products with minerals, vitamins, antioxidants, improvement of organoleptic properties, prolongation of life and antimicrobial packaging of food products. The focus is on the biosafety of nanomaterials whose properties are multifaceted, ambiguous and require a comprehensive, safe, responsible and scientifically sound approach.
\end{abstract}

Keywords: bionanotechnologies, "green" synthesis, metals' nanoparticles, food industry, biosecurity of nanomaterials

\section{INTRODUCTION}

Over the past decades there has been a rapid increase in the number of nanotechnology research. Nanotechnology is an interdisciplinary science that deals with the synthesis of nanomaterials smaller than $100 \mathrm{~nm}$ (Zhiharev and Ljashenko, 2007). Bionatechnology combines biological principles with physical and chemical approaches to obtain nanosized functional particles. New unique properties, including catalytic, electrical, optical, mechanical and electromagnetic properties, have contributed to the production of nanoproducts that have been used in several sectors, such as electronics, medical diagnostics, therapy, agriculture and the food industry. There are various chemical and physical methods used to synthesize nanoparticles. These methods require special expensive equipment and the use of toxic reagents that are not acceptable for large-scale synthesis (Prasanna et al., 2019). Biosynthetic or "green" methods play an extremely important role in nanotechnology, since they are simple, expressive, cost-effective and environmentally friendly (Herrmann et al., 2007) The introduction of the concepts of "green chemistry" and "nanotechnologies" is one of the revolutionary events in science, which has contributed to the research on environmental safety and the reduction of the size of objects. The unification of these two areas paved the way for a new green and nanoscale oriented science called "green nanotechnology" or bionahnotechnology (Das et al., 2017; Thakur et al., 2018). The twelve "principles of green chemistry" are actively suggesting looking for green options for nanoproducts (Das et al., 2017). The principles of green chemistry are a philosophy that is applied in all areas of chemistry, and not just in one chemical discipline, and is aimed at preventing contamination at the molecular level. These principles provide for the application of innovative scientific decisions, which leads to a reduction in the formation of hazardous substances, since it prevents the formation of contaminants. It reduces the negative impact of chemical products and processes on human health and the environment, reduces and even in some cases eliminates the danger from already existing products and processes (Anastas and Eghbali, 2010).

Metals' nanoparticles are one important and widely studied group of materials that show a great deal of diversity and many different uses. The ecological purity of the production of metals' nanoparticles, which application grows at a significant pace, is an urgent problem of the present. The methods of "green" synthesis are environmentally friendly, since organisms have been adapted to survive in environments that contain high levels of metals, developing mechanisms to cope with them. These mechanisms may include the change in the chemical nature of the toxic metal, so that it no longer causes toxicity. That leads to the formation of nanoparticles of the corresponding metal. Thus, the formation of nanoparticles is a "by-product" of the resistance mechanism against a particular metal, and this can be used as an alternative way of obtaining them (Pantidos and Horsfall, 2014).

Nanocomposites are currently being introduced into commercial products at a faster pace than the development of knowledge and regulations to reduce the potential health and environmental impacts associated with their production, use and disposal (Thorley and Tetley 2013). Since nanomaterials find new applications on a daily basis, their potential toxic effects should be monitored (Jain et al 2016). It is necessary to study the influence of nanoparticles on the human body and animals due to their characteristics, namely the method of preparation, size, form, reactivity and other characteristics (Spivak et al 2013; Navya and Daima 2016). After all, it is often unknown how the new materials what are being developed and that appear on commercial markets, after their entry into the environment, will behave. It is important to provide regulatory means to avoid potential risks associated with the continued development and use of nanomaterials, as well as the future development of new materials.

\section{Methods of synthesizing of metals' nanoparticles}

Methods of synthesizing of nanoparticles (NP), including metals nanoparticles $(\mathrm{NPm})$, are improved, new ones are appearing. All methods are aimed at obtaining stable systems, since NPs are characterized by high surface energy and are prone to the formation of large aggregates. Morphology (size and shapes) and properties of nanoparticles depend on the method of synthesis and conduct conditions (Kharissova et al., 2013).

During the last decade, innovative approaches to the synthesis of various nanomaterials such as nanoparticles of metals, quantum dots, carbon nanotubes (fullerenes, graphene, nanotubes) and their composites have appeared in the field 
of nanotechnology (Kim et al., 2007; Laurent et al., 2008; Oskam, 2006; Prasanna et al., 2019; Su et al., 2014). To obtain nanomaterials of the required size, shape and functionality in the existing literature, two different principles of synthesis have been investigated. There are "top-down" and "bottom-up" methods (Fig. 1). Top-down synthesis methods are physical methods of grinding, dispersing volumetric macroforms of metals to nanoparticles using high temperatures, pressure and vacuum (Guozhong, 2004). These methods require complex equipment, are expensive and do not allow adjustment of the size, geometry and stability of nanoparticles of metals (NPm). "Bottom-up" methods are chemical and physico-chemical based on the restoration of metal cations to neutral metal atoms, which unilaterally aggregate to nanosized clusters - NPm (Ge et al., 2013). Currently it is important to transfer of metal ions to zerovalence atoms, and then maintaining the bottom-up synthesis approach up from the bottom (Das et al., 2017). In some cases, depending on the "bottom-up" methods of synthesis and their conditions, it is possible to achieve a state close to monodisperse and its high stability. In some cases, depending on the methods of synthesis "bottom-up", its conditions, it can achieve a state close to monodisperse and its high stability.

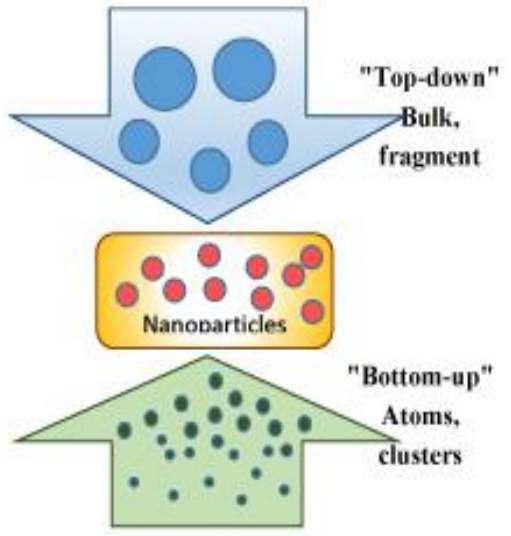

Figure 1 "Top-down" and "bottom-up" synthesis of nanoparticles

Today, the use of nanotechnology advances allows for the production of many polyfunctional materials, but they have shortcomings, such as the use of hazardous chemicals such as sodium borohydride $\left(\mathrm{NaBH}_{4}\right)$ and trinatrium citrate $\left(\mathrm{Na}_{3} \mathrm{C}_{6} \mathrm{H}_{5} \mathrm{O}_{7}\right)$, complex and consumable methods and the lack of scalability of synthesis processes (Das et al., 2017) To evaluate the characteristics of the NPs, their dimensions, size distribution (polydispersity), particle geometry, physical properties (optical, electrical, magnetic, thermal conductivity, etc.) (Jamdagni et al., 2018; Sumitha et al., 2019) are taken into account.

The study of synthesized nanoparticles characteristics is carried out using UVVis spectroscopy, infrared Fourier spectroscopy and fluorescence spectroscopy, transmission and scanning electron microscopy, X-ray diffraction, cyclic voltammetry (Thomas et al., 2019).

However, despite the widespread use of traditional nanoparticle technology, they tend to be expensive, labor-intensive, associated with the risk and potential danger to the environment and living organisms (Santhoshkumar et al., 2017). Thus, there is a clear need for alternative economically feasible and at the same time safe and environmentally friendly methods of nanoparticles production. In order to eliminate the disadvantages of physical and chemical methods, recently bionahnotechnologies ("green" nanotechnologies) are intensively developing (Chauhan et al., 2019; Khan et al., 2017). "Green" synthesis is an environmentally friendly alternative to traditional synthesis methods and aims at avoiding or minimizing toxic components what are used or produced by physical and chemical methods and are able to compete successfully with them in terms of speed, controllability, bioconversion and reduced cost of the final product (Kharissova et al., 2013; Pal et al., 2019; Iravani, 2011).

The advantage of nanostructures synthesized by the "green" approach lies in the fact that bio-objects are used as biofacies contain a large variety of molecules. A the same time they are restoring and stabilizing the surface of synthesized NPs, thus forming coating layers that additionally provide stability and biocompatibility with "green" NPs (Khatami et al., 2018). Although one of the problems encountered by most of the physically and chemically synthesized NPs is aggregation. Biomolecules what cover the surface of the "green" synthesized NPs help to avoid aggregation through the existing coating layer (Khan $\boldsymbol{e t}$ al., 2017; Ahmad et al., 2015; Pal et al., 2019).

There is a large variety of plants in nature, what causes a wide selection of reducing agents able to serve as a material for the synthesis of metals' nanoparticles (Pal et al., 2019). Multicellular and single-celled organisms, due to their ability to accumulate metals, are used for the synthesis of nanoparticles (Sardar and Mazumder, 2019; Singh et al., 2019). During the last decade, it has been shown that diverse biological systems, including plants and algae (Das et al., 2017; Iravani et al., 2011; Roseline et al., 2019), bacteria (Shahverdi et al., 2007; Pantidos and Horsfall, 2014), yeast (Lin et al., 2005), mushrooms
(Narayanan and Saktiivel, 2011b; Chhipa, 2019) and viruses (Shenton et al., 1999; Lee et al., 2002) can convert ions of inorganic metals into metallic nanoparticles due to the recovery process carried out by proteins, enzymes, and metabolites contained in these organisms.

The resulting particles are very promising for biological applications due to their biocompatible nature. Microorganisms in the presence of high metal concentrations have developed specific evolutionary adaptation mechanisms to reduce their toxicity. These mechanisms include the change in the chemical nature of the metal, what leads to the formation of nanoparticles as "by-product" of the adaptive protection mechanism. Such "green" synthesis can be used as an alternative to traditional technologies for the generation of first-generation nanoparticles based on physical and chemical methods (Pantidos and Horsfall, 2014)

It is significant that the production of nanoparticles using plants described in this review has several advantages. There are the availability of cheap material, low toxicity, simplicity, short production times, safety, the ability to regulate the required volume of production, and the suitability for large-scale production among those advantages (Sanjay, 2019). For in vitro biosynthesis, the use of redoxactive components of secondary metabolites of plants is used. In this case, the initiation of the origin of nanoparticles is due to the restoration of metal ions due to reduction compounds / phytochemicals present in tissue extracts. The nuclei are further enhanced by adsorption of metal atoms after recovery, which results in the formation of metals nanoparticles (Rajeshkumar and Bharath, 2017). The components of living cells, such as carbohydrates, fats, proteins, enzymes, flavonoids, terpenoids, polyphenols and alkaloids, can associate metal ions with nanoparticles (Rautela et al., 2019).

The biosynthesis of nanoparticles can be extracellular and intracellular (Iravani, 2014; Santhoshkumar et al., 2017).

Regardless of the nature of the reducing agent, the synthesis of NPs occurs in a series of sequential reactions and interactions, resulting in a balance in the polydisperse system. The following main phases of the "green" synthesis of NPs are singled out: activation (recovery of metal ions $\left(\mathrm{Mn}^{\mathrm{n}+}\right)$ and formation of zerovalent atoms $\left(\mathrm{Me}^{0}\right)$; nucleation of neutral metal atoms with the formation of proton-particles; increasing (aggregation) of smaller particles formed at the nucleation stage and aggregation into larger agglomerates (Makarov et al., 2014)

Intracellular methods for the synthesis of nanoparticles include the cultivation of plants in rich metal organic media (Gardea-Torresdey et al., 2002), in rich soil soils (Haverkamp et al., 2007), as well as in metal-enriched hydroponic solutions (Harris and Bali, 2008). The biosorption of nanoparticles of metals is restored on the periplasmic membrane. Recovery of $\mathrm{Pd}^{2+}$ to $\mathrm{Pd}^{0}$ in the periplasmic membrane was shown (Yong et al., 2002). An enzyme hydrogenase is located on the membrane, what serves as a nucleation site and contributes to the initial growth of Pd nanoparticles, possibly by transporting electrons to recover Pd (II). Non-cellular methods include the synthesis of nanoparticles using an extract of various biological tissues that are prepared in various ways (Pal et al., 2019).

In the extracellular process, the ions are restored with the help of proteins, enzymes and organic molecules in the medium or components of the cell wall. Many organisms have the ability to use the mechanisms of metal recovery, which are synchronously related to the oxidation of enzymes, especially reductase (Deplanche et al., 2010). This leads to the formation of stable and inert metal nanoparticles, which can then be safely removed from the contaminated sample. Extracellular synthesis is more cost-effective than intracellular, because of its lower cost, more simple extraction technology and higher efficacy (Deplanche $\boldsymbol{e}$ al., 2010; Fang et al., 2019).

Methods of "green" chemistry have been actively developed in recent years as an alternative, effective, cheap and environmentally safe method for obtaining polyfunctional nanoparticles with given properties. The priority in green synthesis is the use of non-toxic plants with medicinal properties, which is important for their further use in biology, medicine and food industry.

The overall progress achieved in bionahnotechnology is remarkable, and most importantly, its environmental action has made the "green" synthesis a more generalized and attractive alternative to traditional methods for the synthesis of nanoparticles (Das et al., 2017)

Factors influencing the "green" synthesis of metals' nanoparticles in plants

Synthesis of metals' nanoparticles with the help of plants is environmentally friendly, inaccurate and not expensive and refers to the "green" synthesis. Plants are a good raw material for the "green" synthesis of nanoparticles that have a wide range of applications in various industries (Kumar et al., 2019a; Pal et al., 2019).

The process of restoring metals' ions to form nanoparticles depends on a large number of factors (Kumar et al., 2019a). The nature of the plant extract, the pH of the reaction mixture, the incubation temperature, the reaction time, the concentration, and the electrochemical potential of the metal ion are influenced by the nature of the nanoparticles (Fig. 2) (Raveendran et al., 2003; Haverkamp and Marshall, 2009; Selvakannan et al., 2004; Willett et al., 2005; Yadi et al., 2018). The relationship between the applied parameters, in particular the concentration of the plant extract, the concentration of metal ions, 
the reaction time and temperature with the shape and size of the nanoparticles of the metals obtained (Mishra et al., 2014), have been revealed.

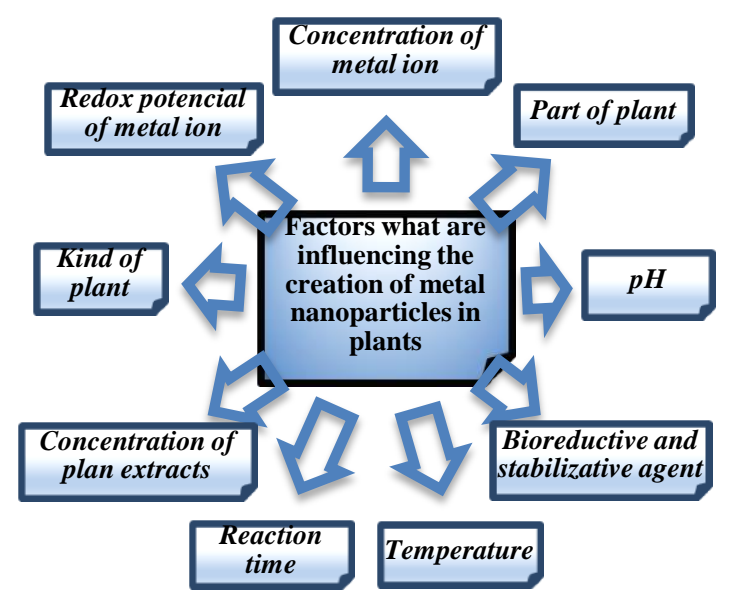

Figure 2 Factors influencing the "green" synthesis of nanoparticles of metals from plant raw materials

The content of active biomolecules, their combination and concentrations are due to the nature of the plant extract. The size and shape of the nanoparticles play a decisive role in determining the overall biocompatibility (Alkilany and Murphy, 2010). For their biomedical applications, nanoparticles with a size up to $100 \mathrm{~nm}$ are the most suitable. It was found that $\mathrm{Ag}$ nanoparticles could be obtained from different plants and their parts, while the sizes of nanoparticles vary. Thus, Ag particles with size $90 \mathrm{~nm}$ were obtained from the leaves of Digitaria radicosa (Naraginti et al., 2016), 11-100 nm from Elephantopus scaber (Kharat and Mendhulkar, 2016), - 20-80 nm from Butea monosperma (Patra et al., 2015), $25 \mathrm{~nm}$ with Thymus serpyllum (Erci and Torlak, 2019). The size of the silver particles obtained from the Diospyros paniculata root is 14-28 nm (Rao et al., 2016), Acorous calamus particles are of an average size of $31 \mathrm{~nm}$ (Naraginti $\boldsymbol{e}$ al., 2016), from Rhizome Curculigo orchioides - 15-18 nm (Kayalvizhi et al., 2016), from fruits of Emblica officinalis 10-70 nm (Ramesh et al., 2015), from Tectona grandis seeds - 10-30 nm (Rautela et al ., 2019), from Durio zibethinus peel - 20-60 nm (Sumitha et al., 2019), from saffron waste (Crocus sativus L.) 12-20 nm (Bagherzade et al., 2017)

Gold nanoparticles can be of different shapes - spherical, cylindrical, cubic, triangular, and different sizes, depending on the nature of the raw materia (Santhoshkumar et al., 2017). Thus, from Carica papaya leaves nanoparticles of size ranging from 15-28 nm were obtained (Muthukumar et al., 2016), from Hibiscus sabdariffa - 10-60 nm (Mishra et al., 2016), from Hygrophila spinosa 50-80 nm (Koperuncholan et al., 2015). Gold nanoparticles from Ocimum sanctum were characterized by different sizes $(1-50,10-300,50-300,>200)$ (Lee et al., 2016). An inexpensive, fast and environmentally friendly approach to the synthesis of AuNPs using A. Rosea leaf extract is proposed. A. Rosea leaves extract can synthesize triangular, pentagonal, hexagonal and spherical AuNPs (Khoshnamvand et al., 2019). Gold nanoparticles derived from banana extract using banana pith extract had antibacterial activity against bacteria as gram positive (Bacillus subtilis) and gram-negative (E.coli, Pseudomonas aeruginosa) (Nayak et al., 2018).

The formation of nanoparticles is influenced by the presence of compounds involving with bioreduction and stabilization (Dauthal and Mukhopadhyay 2016; Ahmed et al., 2014; Kumar et al., 2019a; Khedri et al., 2018). Various photochemical compounds in plant extracts that are involved in the bioreduction of metals' ions act through their synergistic activity. Various photochemica compounds in plant extracts that are involved in the bioreduction of metals' ions act through their synergistic activity (Shankar et al., 2004). Catechins, Teaflavins and Arabugins are required for the formation of gold nanoparticles from Camellia sinensis (Nune et al., 2009; Alshatwi et al., 2015). Similarly, the separation and purification of azadiachratine tetraenotriterpenoide confirmed the role of Azadirachta indica like regenerative and stabilized agent of $\mathrm{Au}$ and $\mathrm{Ag}$ nanoparticles in GS (Shukla et al., 2012). Jatropha curcas, curcain enzyme and the cyclic octapeptide (Curcacycline A and B) play a role in the bioreduction and stabilization of AgNPs synthesized by latex (Bar et al., 2009). According to the "recognition-restriction-limited nucleation and growth" model, in the case of the synthesis of AgNPs, silver-ions were captured on the surface of the protein through electrostatic interaction. (Li et al., 2007). Other researchers deny the involvement of enzymes in the recovery of metal ions, since the herbal extract was heated (Narayanan and Saktiivel 2011a; Song et al., 2010). According to the "recognition-restriction-limited nucleation and growth" model, in the case of the synthesis of AgNPs, silver-ions were captured on the surface of the protein through electrostatic interaction. (Li et al., 2007). Other researchers deny the involvement of enzymes in the recovery of metal ions, since the herbal extract was heated (Narayanan and Saktiivel 2011a; Song et al., 2010).

Polyphenol is used for green synthesis of Pt nanoparticles (Alshatwi et al. 2015), and epicatechin and quercetin-glucuronide were used for $\mathrm{Fe}_{2} \mathrm{O}_{3} \mathrm{NPs}$ (Wang et al., 2014). Common phytochemical components, such as phenols, alkaloids, terpenoids and some pigments are responsible for the "green" synthesis of various low-molecular metals (Das et al., 2010; Nasrollahzadeh et al., 2014; Sangeetha et al., 2011). Different phenolic acids such as caffeic (Aromal and Philip, 2012), ellagic acid (Edison and Sethuraman, 2012), gallic acid (Huang et al., 2010), and protocatechuic acid (Kumar et $\boldsymbol{a l . ,}$ 2012), as well as alkaloids are acting as bioreducting agents for the synthesis of nanoparticles of metals. It is believed that bioreduction of silver and gold ions occurs through the hydroxyl groups of flavonoids (Ghoreishi et al., 2011) and terpenoids (Shankar et al. 2003), oxidized to carbonyl groups and for the use of flavonoid glycoside apine (Kasthuri et al., 2009).

The $\mathrm{pH}$ of the plant extract is very important for the formation of nanoparticles (Armendariz et al., 2004; Ghodake et al., 2010; Sathishkumar et al., 2010) The change in $\mathrm{pH}$ affects the charge of natural extract phytoreagents and their ability to bind and recover metal cations during the synthesis of nanoparticles. These changes contribute to the modification of the shape, size and release of nanoparticles. In the extract of Avena sativa at $\mathrm{pH} 3-4$, golden nanoparticles of small size were formed, while at $\mathrm{pH} 2$, larger aggregated particles were observed. Perhaps this is due to the fact that at $\mathrm{pH} 3-4$ the bigger number of functional groups becomes accessibler than at pH 2 (Sathishkumar et al., 2010). On the contrary, using pear fruit extracts has shown that hexagonal and triangular gold nanoplates are formed in alkaline media, while in the acidic medium nanoparticles are not formed (Ghodake et al., 2010). It is found that significantly more silver nanoparticles from Curcuma longa tubers are synthesized at alkaline pH values (Sathishkumar et al., 2010). The work (Vennila et al., 2018) found that the optimum conditions for the synthesis of silver nanoparticles is the medium of aqueous extract of Spermacoce hispida leaves at $\mathrm{pH} 8$ and $40^{\circ} \mathrm{C}$. AgNPs have been found to have a concentration-dependent antioxidant activity. Experimental results show that if adjusting the size of the synthesized $\mathrm{LF} \mathrm{Al}_{2} \mathrm{O}_{3}$ from Prunus $\times$ yedoensis leaf extract and optimizing its $\mathrm{pH}$, higher catalytic and antibacterial activity is manifested (Manikandan et al., 2019).

Another important factor influencing the formation of nanoparticles in plant extracts is the temperature (Lin et al., 2010; Lukman et al., 2011; Das et al., 2011; Eghbali-Arani et al., 2018; Kumar V. et al., 2019). In general, the temperature increasing helps the reaction rate and the effectiveness of nanoparticle synthesis increasing. In alfalfa ( $M$. sativa), triangular silver nanoparticles are formed only at temperatures above $30^{\circ} \mathrm{C}$ (Lukman et al., 2011). The increase in reaction temperature is accompanied by an increase in the efficiency of the recovery of $\mathrm{Ag}$ ions in the Lemon verbena extracts (Cruz et al., 2010). Moreover, at high temperatures, particles are formed much more often than at room temperature. Temperature can also affects the structural form of synthesized nanoparticles. At room temperature, in Cassia fistula plants, mostly silver nanowires are formed, while at temperatures above $60{ }^{\circ} \mathrm{C}$ the bulk of the spherical nanoparticles is formed (Lin et al., 2010). In this case, it is believed that higher temperatures can changes the interaction of phytoreagents with the surface of nanoparticles, thereby inhibiting the inclusion of adjacent nanoparticles into the structure of the nanoscale. In addition, higher temperatures in some cases may contribute to the nucleation process to the detriment of the secondary recovery process and the subsequent condensation of the metal on the surface of nanoparticles forming. This phenomenon explains the formation of spherical gold nanoparticles at $80^{\circ} \mathrm{C}$ in alcohol extracts Nyctanthes arbor-tristis (night jasmine), in contrast to nanoparticles of various shapes formed at room temperature (Das et al., 2011). The rate of synthesis of AgNPs increased significantly during 2 minutes from the start of $\mathrm{AgNO}_{3}$ incubation with Laminaria japonica algae extract and temperature rise from $90^{\circ} \mathrm{C}$ to $120^{\circ} \mathrm{C}$. A room temperature, it takes $48-72$ hours for completing (Kim et al., 2018). The silver nanoparticles obtained from the leaf extract of Platycodon granddiflorum at $50{ }^{\circ} \mathrm{C}$ had an average size of $21 \mathrm{~nm}$ while a temperature of $30^{\circ} \mathrm{C}$ was $19 \mathrm{~nm}$ In general, low frequency synthesized at $50{ }^{\circ} \mathrm{C}$ had a good shape and structure with high stability (-5.23) (Anbu et al., 2019).

In determining the shape, size, and speed of the nanoparticle recovery process, the concentration of plant extracts plays an important role (Kumar et al., 2019b) When used for the synthesis of AgNPs and AuNPs of fruit extract (Tanacetum vulgare) at concentrations of $0.5 \mathrm{ml}, 1.0 \mathrm{ml}, 1.8 \mathrm{ml}, 2.8 \mathrm{ml}, 3.8 \mathrm{ml}$ and $4.8 \mathrm{ml}$, a decrease in the size of the particles was observed with an increase concentration of extract (Dubey et al., 2010). Similar results were obtained for the synthesis of AgNPs and AuNPs from the leaf extract of Chenopodium album (Dwivedi and Gopal, 2010). The average size of AgNPs obtained from C. amboinicus (Narayanan and Sakthivel, 2011a) and Carica papaya peel extract (Balavijayalakshmi and Ramalakshmi, 2017) decreased with increasing extracts concentration. The shape, size and yield of nanoparticles in green synthesis depend on the time of incubation / reaction. During the AgNPs synthesis using the extract of Capsicum annuum $L$. at $5 \mathrm{~h}$ incubation time, the nanoparticles were spherical and their size was $10 \pm 2 \mathrm{~nm}$. In the case of increasing the incubation time to 9 and 13 hours, the size of the nanoparticles increased to $25 \pm 3 \mathrm{~nm}$ and $40 \pm 5 \mathrm{~nm}$, respectively (Li et al., 2007). 
Concentration of metals' is also influencing the synthesis of nanoparticles (Kumar et al., 2019a). Dubey et al., (2010) synthesized AgNPs and AuNPs using fruit musk extract at different concentrations of metals' ions (1-3 mM) Increasing in the concentration of silver ions led to an increase in the absorption peak in the case of AgNP, but in the case of AuNPs, the absorption peak increased at $1 \mathrm{mM}$ and $2 \mathrm{mM}$ gold ion concentrations, while peak absorption decreased with $3 \mathrm{mM}$ gold ions. At a higher concentration of metal ions, AgNPs were larger. In addition, they observed that an increase in the reaction time resulted in an increase in the acute absorption peak for both AgNP and AuNP The efficiency of the synthesis of metals' nanoparticles also depends on the ion electrochemical potential (Haverkamp R. and Marshall, 2009; Sims et al., 2017). Thus, the ability of a plant extract to effectively regenerate metal ions can be significantly higher in the case of ions with a large positive electrochemical potential $\left(\mathrm{eg}, \mathrm{Ag}^{+}\right)$than in low-electrochemical potential ions such as $\left.\left.\left[\mathrm{Ag}\left(\mathrm{S}_{2} \mathrm{O}_{3}\right)_{2}\right]^{3-}\right)\right]$ (Haverkamp and Marshall, 2009). AuNPs superficial charge, calculated on the zeta potential basis, facilitates their physical and chemical stability and further involvement in metabolism and bioaccumulation (Sengani $\boldsymbol{e t}$ al., 2017). The toxicity level of AuNPs strongly depends on the charge of surface particles, so positively charged gold nanoparticles cause cell death at lower concentrations, while neutrally charged particles detect cell death at much higher concentrations (He et al., 2017).

The proteins that make up the herbal extract can significantly influence the formation of nanoparticles (Saravanakumar et al., 2018). Recently, the "green" synthesis of metals' nanoparticles uses approach combining the use of plan extracts with the addition of biomaterial, peptides and proteins, the amino acid sequence and structure of those amino acids optimized for the effective production of nanoparticles. The best ability to recover metal ions belongs to tryptophan, tyrosine, arginine and lysine (Selvakannan et al., 2004). ZnO nanoparticles of 30 to $50 \mathrm{~nm}$ containing functional molecules such as carboxylic acids, amines and nitro groups obtained from the Cassia alata plant. They had anti-dermatophytic potential against Trichophyton mentagrophyte, Trichophyton rubrum, Epidermophyton floccosum, Microsporum audouinii and Microsporum canis (Sujatha et al., 2018).

\section{Nanomaterials in the food industry}

In modern conditions, nanotechnologies are increasingly becoming widespread, especially in the food industry (Patel et al., 2018; Hamad et al., 2018; Sonawane et al., 2018). Nanotechnologies have the potential providing healthier, safer and better food, as well as improved packaging of food products. The application of nanotechnologies in the food industry will contribute to the creation of new materials through a range of their unique physical and chemical properties, useful for a number of other industries (Dasarahally-Huligowda $\boldsymbol{e}$ al., 2019). It is promising to apply nanotechnological approaches to the entire chain of agricultural production, from the field to consumers (Bityutskyy et al. 2017; Fortunati et al., 2019). This involves the creation and use of organic and inorganic materials in a nanoscale, with individual physical, chemical and biological properties. It had been established that substances in the form of nanoparticles, in comparison with molecular and macroscopic forms, have for the most part different physical and chemical properties (Jafarizadeh-Malmiri et al., 2019c).

The field of nanotechnology in the food industry is rapidly developing and has various applications in the food analysis (Nurfatihah and Siddiquee, 2019), the application of nanosensors (Ragavan and Neethirajan, 2019; HernándezMuñoz et al., 2019), tracking devices, packaging (Jafarizadeh-Malmiri et al., 2019a; Hernández-Muñoz et al., 2019) etc. Nanotechnologies at various levels in the food industry, including food packaging, food processing, and various conservation methods aimed at increasing the shelf life of the food (Hamad $\boldsymbol{e}$ al., 2018). Nanotechnologies are successfully used to ensure the quality of food and food safety (detection of pathogenic microorganisms or toxic metabolites), enrichment of food products (minerals, vitamins, antioxidants and essential oils), improvement of organoleptic properties (increase of taste or color), extension of shelf life and antimicrobial food packaging (Chen et al., 2017; Duncan, 2011; Hamad et al., 2018). Nanotechnologies for intelligent packaging developing are focusing mainly on protecting the product from oxygen, moisture and maintaining freshness (Cabedo et al., 2018; Oh et al., 2019). Functional packaging should have increased mechanical strength, barrier properties, flexibility and stability, be capable of biological decomposition, low-yielding and environmentally friendly (Kuswandi and Moradi, 2019).

Commonly accepted methods for detecting pathogens transmitting by food or their toxic metabolites are time-consuming and expensive compared to nanotechnology methods that are faster, more accurate, and more cost-effective (Bata-Vidács et al., 2013; Choleva et al., 2018; Liao et al., 2018).

Nanomaterials are generally classified as: nanoparticles, nanomolecules, nanoemulsions, nanolaminates, nanocapsules, nanofibers, nanotubes etc. (Fig. 3), which can be synthesized by many methods and have many applications in the food industry (Liu et $\boldsymbol{a l}$., 2018). Nanomaterials can be used as nutritiona supplements (nanoinsiders) and as food packaging (nanooutsiders) (Ranjan et al., 2014).
Biopolymer nanoparticles can be formed using biopolymers of food quality, namely, proteins or polysaccharides by self-concentration or aggregation Polylactoglicolic acid is used to encapsulate and deliver medications, trace elements and vitamins (Ravichandran, 2010).

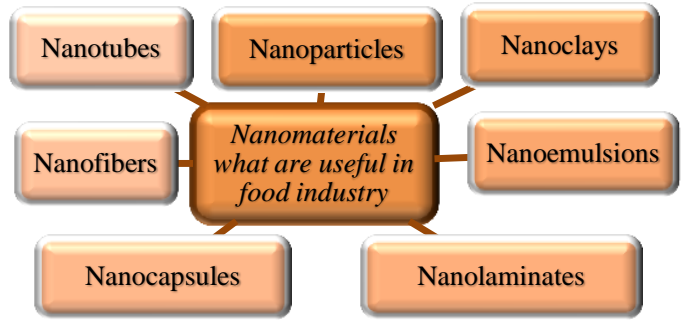

Figure 3 Nanomaterial's what are useful in food industry

Nanoemulsions with droplets diameter less than 100-500 $\mathrm{nm}$ in diameter can be included in functional food ingredients (Ranjan et al., 2014; Artiga-Artigas et al., 2019). Substances with common nanosilver and nanoclay structure can act as a barrier to gas and moisture (Akbari et al., 2006; Cabedo et al., 2018). These nanocomposites are potentially used in packaging for cheese, confectionery, processed meat and cereal products (Cagri et al., 2004; King et al., 2018). An additional application includes an extrusion coating for fruit juices, liquid dairy products, as well as beer and carbonated drinks (Akbari et al., 2006; Jafarizadeh-Malmiri et al., 2019b).

Nanolaminates consist of two or more layers of nanosized material and physically or chemically bonded to each other. They may contain edible nanolaminates constructed of polysaccharides, proteins and lipids (Ravichandran, 2010). They can be built in the form of food coats and films for a variety of food products such as vegetables, fruits, meat, candy, chocolate, bakery products. Such a coating or film serves as a barrier to moisture, gas and lipids. In addition, nanolaminates can be carriers of functional components, namely flavors, dyes, antimicrobial compounds, antioxidants, and improve the texture properties of various foods (Ranjan et al., 2014).

Nanocapsules are made of lipids or natural polymers and they are widely used in foods (Ponce $\boldsymbol{e t}$ al., 2018). The formation of nanocapsule involves the inclusion of bioactive compounds in small particles. Encapsulation using nanoemulsions is a powerful technique for protecting food ingredients, including vitamins, lipids, antioxidants and antimicrobial agents. (Kumar and Sarkar, 2018) Immobilization of the enzyme on the appropriate carriers increases their functional efficiency and reproducibility while reducing the complexity and reducing the contamination. They are useful in baking, making dairy products, jams, jellies, processing beverages (beer, wine, juices) (Sneha et al., 2019). Rosemary extract nanocapsule with natural antimicrobial polysaccharide chitosan and $\gamma$-polyglutamic acid ( $\gamma$-PGA) is used to improve antimicrobial activity (Lee et al., 2019).

Nanotubes could be made of several globular proteins and be useful to enhance the processes of immobilization of enzymes (Singh, 2016)

The complexity of preserving food is due to the largely inappropriate use of antibiotics. The use of nanomaterials with antimicrobial activity is a new protection from many drug-resistant infectious organisms (Bata-Vidács et al., 2013). Instead of interfering with a certain biochemical process, as conventional antibiotics do, nanoparticles are likely to inhibit several processes in microorganism cells in a less specific manner. Nanoscale materials that possess antimicrobial properties include nanoparticles based on silver oxide $\left(\mathrm{Ag}_{2} \mathrm{O}\right)$ (Allahverdiyev et al., 2011), Titanium dioxide $\left(\mathrm{TiO}_{2}\right)($ Chawengkijwanich and Hayata 2008), copper and copper oxide (CuO) (Chauhan et al., 2019), zinc oxide (ZnO) (Paul et al., 2019), cerium dioxide (Tsekhmistrenko et al., 2018a) Among them, silver nanoparticles (AgNPs) are the most powerful anti-microbial agents of a wide spectrum of action. Conventional antibiotics eradicate only 5-6 pathogens, while silver molecules can destroy more than 650 pathogens in 6 minutes of contact (Han and $\mathbf{L i , ~ 2 0 0 8}$ ). This indicates the possibility of their use as a preservative and packaging material due to their safe condition and low cost (Akbar et al., 2019).

Polypropylene films coated with $\mathrm{TiO}_{2}$ nanoparticles exhibited photoconductive biocidal properties against nine food bacteria and yeasts (Cerrada et al., 2008) which were able to inhibit the growth of $E$ coli in freshly cut salad (Chawengkijwanich and Hayata 2008). Silver nanoparticles (AgNPs) exhibited greater killing power than vancomycin (Gu et al., 2003).

Enzyme-like activity of metals' nanoparticles allow them to be widely used in various industries (Cormode et al., 2018; Li et al., 2018; Wang et al., 2016; Tsekhmistrenko et al., 2018b). The activity of peroxidase and oxidase are exhibited by iridium nanoparticles (Cui et al., 2017), rhodium (Choleva $\boldsymbol{e t}$ al., 2018), ruthenium (Cao et al., 2017), cerium oxide (Estevez et al., 2017), manganese oxide (Yan et al., 2017), cobalt compounds (Jia et al., 2016; Wang et al., 2017; Zhao et al., 2018), $\mathrm{NiCo}_{2} \mathrm{O}_{4}$ (Song et al., 2018).

Nanotechnology applications in the food sector are expected to bring a number of benefits, including new flavors and product texture, less use of fats, and 
improved nutrient uptake (Ponce et $\boldsymbol{a l}$., 2018). The nanosensory devices will allow rapid, selective, responsive, cost-effective and, in some cases, built-in, online, and real-world detection of a wide range of compounds, even in compound matrices, and may allow the development of new strategies for detecting allergens (Gómez-Arribas et al., 2018).

Packages with nanocomposites of metals have a number of advantages, including reduction of the use of preservatives, higher rate of reactions for suppressing microbial growth, extending the shelf life of food products (Hoseinnejad $\boldsymbol{e t}$ al., 2018). As biosensors for assessing the quality and safety of food products, nanoparticles are used (Ragavan and Neethirajan, 2019; Jafarizadeh-Malmiri et al., 2019c).

The most promising is the use of nanoparticles obtained by the "green" synthesis method (Dwivedy et al., 2019). However, the use of nanoparticles in all industries should be clearly controlled, as there is a report on the toxicity of individual nanomaterials (Jain et al., 2018; Das et al., 2019).

\section{Risks of using metals' nanoparticles}

The widespread use of metals' nanoparticles and their oxides is not possible without assessing their potential impact on end users (Kaphle et al., 2018). The issues of biosafety of nanomaterials are multifaceted and ambiguous, requiring an integrated, safe, responsible and scientifically grounded approach (Communication, 2008). There are currently not enough reports on the toxicodynamics and toxicokinetics of nanoparticles in humans and animals and their impact on the environment (Kaphle et al., 2018). To this end, it is necessary to systematize information on the interrelationships between the toxicity of nanoparticles and their composition, concentration, size, form, reactivity, etc. (Navya and Daima 2016). It is important to investigate the molecular mechanisms of the influence of nanoparticles on the body, organs, tissues, cells and mechanisms of development of remote toxic effects, as well as ways to eliminate or weaken their undesirable effects. The pollution of nanoparticles, and, consequently, the change in their properties is reported not only in the environment but also in the food production chain, which has an impact on humans almost inevitable (Mattarozzi et al., 2019). Nanotechnologies improve our lives, especially in nutrition. They could provide potential problems which could not be ignored (Ummi and Siddiquee, 2019). Such studies are possible in case of use of key system characteristics of biological systems in vivo and in vitro (physiological, biochemical, immunological, genetic, cytological, etc.) that are susceptible to toxic effects (Roman'ko M. E., 2017; Prajitha et al., 2019) The toxic effects of nanoparticles may be due to the fact that they are capable of penetrating the cell bypassing the respiratory, skin, gastrointestinal, hematoencephalic, placental and other barriers and selectively accumulate in cells and sub-cell structures (Colon et al., 2009; Fischer and Chan 2007; Ranjan et al., 2018)

The food industry intensively uses silver nanoparticles as sensors, nutritional supplements, and packaging components. However, they present a potential toxicity risk for the consumer, the target of which is the intestine and liver. Silver nanoparticles can produce free radicals and cause oxidative stress in cells, causing oxidative damage. Oxidative stress mediates toxicity, causing inflammatory reactions and death from necrosis or apoptosis (Gaillet and Rouanet, 2015).

It is necessary to balance the efficiency and toxicity of nanomaterials before using such materials (Thorley and Tetley 2013). Nanomaterials what are intended for use in foods and for therapeutic purposes should be thoroughly investigated in silico, in vitro and in vivo toxicity analysis (Jain et al., 2016). For these innovative systems, additional research needs to achieve minimal side effects and a wide range of applications.

\section{Conclusions and perspectives of further research}

Among a number of methods used to synthesize nanoparticles of metals and metal oxides, a "green" synthesis based on plants deserves a great deal of attention, due to its environmental friendliness. There is a large array of reports about the possibility of synthesizing nanoparticles from different parts of plants, including leaves, stems, bark, flowers, roots, peas, fruits and seeds. The size and shape of nanoparticles are controlling by physical and chemical parameters. The peculiarity of the "green" synthesis of nanoparticles is the difficulty of explaining the mechanisms of synthesis, prediction and identification of specific bioreducting and stabilizing molecules. The size, shape and properties of nanoparticles obtained by nanotechnological methods depend on the type and part of plants, temperature, reaction of the medium, concentration of metal ions and other parameters. Studying features of metals nanoparticles synthesis from plant raw materials and their specific properties will provide wide application in biology, medicine, agriculture, and in the food industry. All this together will contribute to improving the health of people, the duration and quality of life.

\section{REFERENCES}

AHMAD, A., SYED, F., SHAH, A., KHAN, Z., TAHIR, K., KHAN, A. U. \& YUAN, Q. 2015. Silver and gold nanoparticles from Sargentodoxa cuneata: synthesis, characterization and antileishmanial activity. RSC Advances, 5(90), 73793-73806. DOI:10,1039 / C5RA13206A

AHMED, S., AHMAD, M., \& IKRAM, S. 2014. Chitosan: a natural antimicrobial agent-a review. Journal of Applicable Chemistry, 3(2), 493-503. AKBAR, A., SADIQ, M.B., ALI, I., MUHAMMAD, N., REHMAN, Z., KHAN, M.N., ... \& ANAL, A.K. 2019. Synthesis and antimicrobial activity of zinc oxide nanoparticles against foodborne pathogens Salmonella typhimurium and Staphylococcus aureus. Biocatalysis and Agricultural Biotechnology, 17, 36-42. https://doi.org/10.1016/j.bcab.2018.11.005

AKBARI, Z., GHOMASHCHI, T., \& AROUJALIAN, A. 2006. Potential of nanotechnology for food packaging industry. Proceedings of "Nano and Micro Technologies in the Food and HealthFood Industries, 25-26.

ALKILANY, A. M., \& MURPHY, C. J. 2010. Toxicity and cellular uptake of gold nanoparticles: what we have learned so far?. Journal of nanoparticle research, 12(7), 2313-2333. https://doi.org/10.1007/s11051-010-9911-8

ALLAHVERDIYEV, A. M., ABAMOR, E. S., BAGIROVA, M., \& RAFAILOVICH, M. 2011. Antimicrobial effects of $\mathrm{TiO}_{2}$ and $\mathrm{Ag}_{2} \mathrm{O}$ nanoparticles against drug-resistant bacteria and leishmania parasites. Future microbiology, 6(8), 933-940. https://doi.org/10.2217/fmb.11.78

ALSHATWI, A. A., ATHINARAYANAN, J., \& SUBBARAYAN, P. V. 2015. Green synthesis of platinum nanoparticles that induce cell death and G2/M-phase cell cycle arrest in human cervical cancer cells. Journal of Materials Science: Materials in Medicine, 26(1), 7. https://doi.org/10.1007/s10856-014-5330-1

ANASTAS, P., \& EGHBALI, N. 2010. Green chemistry: principles and practice. Chemical Society Reviews, 39(1), 301-312. DOI: 10.1039/ B918763B

ANBU, P., GOPINATH, S. C., YUN, H. S., \& LEE, C. G. 2019. Temperaturedependent green biosynthesis and characterization of silver nanoparticles using balloon flower plants and their antibacterial potential. Journal of Molecular Structure, 1177, 302-309. https://doi.org/10.1016/j.molstruc.2018.09.075

ARMENDARIZ, V., HERRERA, I., JOSE-YACAMAN, M., TROIANI, H., SANTIAGO, P., \& GARDEA-TORRESDEY, J. L. 2004. Size controlled gold nanoparticle formation by Avena sativa biomass: use of plants in nanobiotechnology. Journal of Nanoparticle Research, 6(4), 377-382. https://doi.org/10.1007/s11051-004-0741-4

AROMAL, S. A., \& PHILIP, D. 2012. Green synthesis of gold nanoparticles using Trigonella foenum-graecum and its size-dependent catalytic activity. Spectrochimica Acta Part A: Molecular and Biomolecular Spectroscopy, 97, 1-5 https://doi.org/10.1016/j.saa.2012.05.083

ARTIGA-ARTIGAS, M., ODRIOZOLA-SERRANO, I., OMS-OLIU, G., \& MARTIN-BELLOSO, O. 2019. Nanostructured Systems to Increase Bioavailability of Food Ingredients. In Nanomaterials for Food Applications (pp 13-33). Elsevier. https://doi.org/10.1016/B978-0-12-814130-4.00002-6

BAGHERZADE, G., TAVAKOLI, M. M., \& NAMAEI, M. H. 2017. Green synthesis of silver nanoparticles using aqueous extract of saffron (Crocus sativus L.) wastages and its antibacterial activity against six bacteria. Asian Pacific Journal of Tropical Biomedicine, 7(3), 227-233. https://doi.org/10.1016/j.apjtb.2016.12.014

BALAVIJAYALAKSHMI, J., \& RAMALAKSHMI, V. 2017. Carica papaya peel mediated synthesis of silver nanoparticles and its antibacterial activity against human pathogens. Journal of applied research and technology, 15(5), 413-422. https://doi.org/10.1016/j.jart.2017.03.010

BAR, H., BHUI, D. K., SAHOO, G. P., SARKAR, P., DE, S. P., \& MISRA, A 2009. Green synthesis of silver nanoparticles using latex of Jatropha curcas. Colloids and surfaces A: Physicochemical and engineering aspects, 339(1-3), 134-139. https://doi.org/10.1016/j.colsurfa.2009.02.008

BATA-VIDÁCS, I., ADÁNYI, N., BECZNER, J., FARKAS, J., \& SZÉKÁCS, A. 2013. Nanotechnology and microbial food safety. Microbial pathogens and strategies for combating them: science, technology and education. Formatex, Zubaran, 155-159.

BITYUTSKYY, V.S., TSEKHMISTRENKO, O.S., TSEKHMISTRENKO, S.I. SPYVACK, M.Y., SHADURA, U.M. 2017. Perspectives of cerium nanoparticles use in agriculture. The Animal Biology. 19(3), 9-17. https://dx.doi.org/10.15407/animbioll119.03.009

CABEDO, L., \& GAMEZ-PEREZ, J. 2018. Inorganic-Based Nanostructures and Their Use in Food Packaging. In Nanomaterials for Food Packaging, 13-45. https://doi.org/10.1016/B978-0-323-51271-8.00002-4

CAGRI, A., USTUNOL, Z., \& RYSER, E. T. 2004. Antimicrobial edible films and coatings. Journal of food protection, 67(4), 833-848. https://doi.org/10.4315/0362-028X-67.4.833

CAO, G. J., JIANG, X., ZHANG, H., CROLEY, T. R., \& YIN, J. J. 2017 Mimicking horseradish peroxidase and oxidase using ruthenium nanomaterials. RSC Advances, 7(82), 52210-52217. https://doi.org/10.1039/C7RA10370K

CERRADA, M. L., SERRANO, C., SANCHEZ-CHAVES, M., FERNANDEZGARCIA, M., FERNANDEZ-MARTIN, F., DE ANDRES, A., ... \& FERNÁNDEZ-GARCÍA, M. 2008. Self-sterilized EVOH-TiO ${ }_{2}$ nanocomposites: interface effects on biocidal properties. Advanced Functional Materials, 18(13), 1949-1960. https://doi.org/10.1002/adfm.200701068

CHAUHAN, M., SHARMA, B., KUMAR, R., CHAUDHARY, G. R., HASSAN, A. A., \& KUMAR, S. 2019. Green synthesis of $\mathrm{CuO}$ nanomaterials and their proficient use for organic waste removal and antimicrobial application 
Environmental

research,

168

$85-95$ https://doi.org/10.1016/i.envres.2018.09.024

CHAWENGKIJWANICH, C., \& HAYATA, Y. 2008. Development of $\mathrm{TiO}_{2}$ powder-coated food packaging film and its ability to inactivate Escherichia coli in vitro and in actual tests. International journal of food microbiology, 123(3), 288-292. https://doi.org/10.1016/j.ijfoodmicro.2007.12.017

CHEN, S., QUAN, Y., YU, Y. L., \& WANG, J. H. 2017. Graphene quantum dot/silver nanoparticle hybrids with oxidase activities for antibacterial application. ACS Biomaterials Science \& Engineering, 3(3), 313-321. https://doi.10.1021/acsbiomaterials.6b00644

CHHIPA, H. 2019. Mycosynthesis of nanoparticles for smart agricultural practice: A green and eco-friendly approach. In Green Synthesis, Characterization and Applications of Nanoparticles (pp. 87-109). Elsevier. https://doi.org/10.1016/B978-0-08-102579-6.00005-8

CHOLEVA, T. G., GATSELOU, V. A., TSOGAS, G. Z., \& GIOKAS, D. L 2018. Intrinsic peroxidase-like activity of rhodium nanoparticles, and their application to the colorimetric determination of hydrogen peroxide and glucose. Microchimica Acta, 185(1), 22. https://doi.org/10.1007/s00604-017-2582-8 COLON, J., HERRERA, L., SMITH, J., PATIL, S., KOMANSKI, C. KUPELIAN, P., .. \& BAKER, C. H. 2009. Protection from radiation-induce pneumonitis using cerium oxide nanoparticles. Nanomedicine: Nanotechnology, Biology and Medicine, 5(2), 225-231. https://doi.org/10.1016/j.nano.2008.10.003 Communication from the Commissionto the European Parlament, the Council and the European Economic and Social Committee. Regulatory aspects of nanomaterials. SEC2008 2036 / Commission of the European Communities.

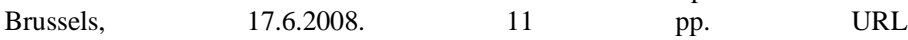
https://ec.europa.eu/research/industrial technologies/pdf/policy/comm 2008036 6 en.pdf.

CORMODE, D. P., GAO, L., \& KOO, H. 2018. Emerging Biomedica Applications of Enzyme-Like Catalytic Nanomaterials. Trends in biotechnology, 36(1), 15-29 https://doi.org/10.1016/j.tibtech.2017.09.006

CRUZ, D., FALÉ, P. L., MOURATO, A., VAZ, P. D., SERRALHEIRO, M. L., \& LINO, A. R. L. 2010. Preparation and physicochemical characterization of Ag nanoparticles biosynthesized by Lippia citriodora (Lemon Verbena). Colloids and $\begin{array}{llll}\text { Surfaces } & \text { B: } & \text { Biointerfaces, } & \text { 81(1), }\end{array}$ https://doi.org/10.1016/j.colsurfb.2010.06.025

CUI, M., ZHAO, Y., WANG, C., \& SONG, Q. 2017. The oxidase-like activity of iridium nanoparticles, and their application to colorimetric determination of dissolved oxygen. Microchimica Acta, 184(9), 3113-3119. https://doi.10.1007/s00604-017-2326-9

DAS, M., \& CHATTERJEE, S. 2019. Green synthesis of metal/metal oxide nanoparticles toward biomedical applications: Boon or bane. In Green Synthesis, Characterization and Applications of Nanoparticles (pp. 265-301). Elsevier. https://doi.org/10.1016/B978-0-08-102579-6.00011-3

DAS, R. K., BORTHAKUR, B. B., \& BORA, U. 2010. Green synthesis of gold nanoparticles using ethanolic leaf extract of Centella asiatica. Materials Letters, 64(13), 1445-1447. https://doi.org/10.1016/j.matlet.2010.03.051

DAS, R. K., GOGOI, N., \& BORA, U. 2011. Green synthesis of gold nanoparticles using Nyctanthes arbortristis flower extract. Bioprocess and biosystems engineering, 34(5), 615-619. https://doi.org/10.1007/s00449-010$\underline{0510}$

DAS, R. K., PACHAPUR, V. L., LONAPPAN, L., NAGHDI, M PULICHARLA, R., MAITI, S., ... \& BRAR, S. K. 2017. Biological synthesis of metallic nanoparticles: plants, animals and microbial aspects. Nanotechnology for Environmental Engineering, 2(1), 18. https://doi.org/10.1007/s41204-017-0029-4 DASARAHALLY-HULIGOWDA, L. K., GOYAL, M. R., \& SULERIA, H. A R. 2019. Nanotechnology Applications in Dairy Science: Packaging, Processing, and Preservation. https://doi.org/10.1201/9780429425370

DAUTHAL, P., \& MUKHOPADHYAY, M. 2016. Noble metal nanoparticles: plant-mediated synthesis, mechanistic aspects of synthesis, and applications Industrial \& Engineering Chemistry Research, 55(36), 9557-9577. DOI: 10.1021 / acs.iecr.6b00861

DEPLANCHE, K., CALDELARI, I., MIKHEENKO, I. P., SARGENT, F. \& MACASKIE, L. E. 2010. Involvement of hydrogenases in the formation of highly catalytic Pd (0) nanoparticles by bioreduction of Pd (II) using Escherichia coli mutant strains. Microbiology, 156(9), 2630-2640. doi: 10.1099 mic.0.036681-0

DUBEY, S. P., LAHTINEN, M., \& SILLANPÄÄ, M. 2010. Tansy fruit mediated greener synthesis of silver and gold nanoparticles. Process Biochemistry, 45(7), 1065-1071. https://doi.org/10.1016/j.procbio.2010.03.024

DUNCAN, T. V. 2011. Applications of nanotechnology in food packaging and food safety: barrier materials, antimicrobials and sensors. Journal of colloid and interface science, 363(1), 1-24. https://doi.org/10.1016/j.jcis.2011.07.017

DWIVEDI, A. D. \& GOPAL, K. 2010. Biosynthesis of silver and gold nanoparticles using Chenopodium album leaf extract. Colloids and Surfaces A: Physicochemical and Engineering Aspects, 369(1-3), 27-33. https://doi.org/10.1016/j.colsurfa.2010.07.020

DWIVEDY, A. K., UPADHYAY, N., ASAWA, S., KUMAR, M., PRAKASH, B., \& DUBEY, N. K. 2019. Therapeutic Potential of Plant-Based Metal Nanoparticles: Present Status and Future Perspectives. In Nanomaterials in
Plants, Algae and Microorganisms (pp. 169-196). Academic Press. https://doi.org/10.1016/B978-0-12-811488-9.00009-3

EDISON, T. J. I., \& SETHURAMAN, M. G. 2012. Instant green synthesis of silver nanoparticles using Terminalia chebula fruit extract and evaluation of their catalytic activity on reduction of methylene blue. Process Biochemistry, 47(9), 1351-1357. https://doi.org/10.1016/j.procbio.2012.04.025

EGHBALI-ARANI, M., SOBHANI-NASAB, A., RAHIMI-NASRABADI, M., \& POURMASOUD, S. 2018. Green Synthesis and Characterization of SmVO 4 Nanoparticles in the Presence of Carbohydrates As Capping Agents with Investigation of Visible-Light Photocatalytic Properties. Journal of Electronic Materials, 1-13. https://doi.org/10.1007/s11664-018-6236-3

ERCI, F., \& TORLAK, E. 2019. Antimicrobial and antibiofilm activity of green synthesized silver nanoparticles by using aqueous leaf extract of Thymus serpyllum. Sakarya University Journal of Science, 23(3), 1-1. https://dx.doi.org/10.16984/saufenbilder.445146

ESTEVEZ, A. Y., STADLER, B., \& ERLICHMAN, J. S. 2017. In-vitro Analysis of Catalase-, Oxidase-and SOD-mimetic Activity of Commercially Available and Custom-synthesized Cerium Oxide Nanoparticles and Assessment of Neuroprotective Effects in a Hippocampal Brain Slice Model of Ischemia. The FASEB Journal, 31(1 Supplement), 693-5.

FANG, X., WANG, Y., WANG, Z., JIANG, Z., \& DONG, M. (2019) Microorganism Assisted Synthesized Nanoparticles for Catalytic Applications. Energies, 12(1), 190. https://doi.org/10.3390/en12010190

FISCHER, H. C., \& CHAN, W. C. 2007. Nanotoxicity: the growing need for in vivo study. Current opinion in biotechnology, 18(6), 565-571. https://doi.org/10.1016/i.copbio.2007.11.008

Fortunati, E., Mazzaglia, A., \& Balestra, G. M. 2019. Sustainable control strategies for plant protection and food packaging sectors by natural substances and novel nanotechnological approaches. Journal of the Science of Food and Agriculture, 99(3), 986-1000. https://doi.org/10.1002/jsfa.9341

GAILLET, S., \& ROUANET, J. M. 2015. Silver nanoparticles: their potential toxic effects after oral exposure and underlying mechanisms-a review. Food and Chemical Toxicology, 77, 58-63. https://doi.org/10.1016/j.fct.2014.12.019

GARDEA-TORRESDEY, J. L., PARSONS, J. G., GOMEZ, E., PERALTAVIDEA, J., TROIANI, H. E., SANTIAGO, P. \& YACAMAN, M. J. 2002. Formation and growth of Au nanoparticles inside live alfalfa plants. Nano letters, 2(4), 397-401. DOI: 10,1021 / n1015673 +

GE, L., LI, Q., WANG, M., OUYANG, J., LI, X. \& XING, M. M. 2014 Nanosilver particles in medical applications: synthesis, performance \& toxicity. International journal of nanomedicine, 9, 2399. https://www.ncbi.nlm.nih.gov/pmc/articles/PMC4037247/

GHODAKE, G. S., DESHPANDE, N. G., LEE, Y. P., \& JIN, E. S. 2010. Pear fruit extract-assisted room-temperature biosynthesis of gold nanoplates. Colloids $\begin{array}{llll}\text { and } \quad \text { Surfaces } & \text { B: } \quad \text { Biointerfaces, } & \text { 75(2), 584-589. }\end{array}$ https://doi.org/10.1016/j.colsurfb.2009.09.040

GHOREISHI, S. M., BEHPOUR, M., \& KHAYATKASHANI, M. 2011. Green synthesis of silver and gold nanoparticles using Rosa damascena and its primary application in electrochemistry. Physica E: Low-dimensional Systems and Nanostructures, 44(1), 97-104. https://doi.org/10.1016/j.physe.2011.07.008 GÓMEZ-ARRIBAS, L., BENITO-PEÑA, E., HURTADO-SÁNCHEZ, M., \& MORENO-BONDI, M. 2018. Biosensing based on nanoparticles for food allergens detection. Sensors, 18(4), 1087. https://doi.org/10.3390/s18041087

GU, H., HO, P. L., TONG, E., WANG, L., \& XU, B. 2003. Presenting vancomycin on nanoparticles to enhance antimicrobial activities. Nano letters, 3(9), 1261-1263. DOI: $10.1021 / \mathrm{nl} 1034396 \mathrm{z}$

GUOZHONG, C. 2004. Nanostructures and nanomaterials: synthesis, properties and applications. World scientific.

HAMAD, A. F., HAN, J. H., KIM, B. C., \& RATHER, I. A. 2018. The intertwine of nanotechnology with the food industry. Saudi journal of biological sciences, 25(1), 27-30. https://doi.org/10.1016/j.sibs.2017.09.004

HAN, M., \& LI, S. 2008. Study on the medical application of silver material. In Micro-and Nanotechnology: Materials, Processes, Packaging, and Systems IV (Vol. 7269, p. 726917). International Society for Optics and Photonics. https://doi.org/10.1117/12.805550

HARRIS, A. T. \& BALI, R. 2008. On the formation and extent of uptake of silver nanoparticles by live plants. Journal of Nanoparticle Research, 10(4), 691 695. doi.10.1007/s11051-007-9288-5

HAVERKAMP, R. G., \& MARSHALL, A. T. 2009. The mechanism of metal nanoparticle formation in plants: limits on accumulation. Journal of Nanoparticle Research, 11(6), 1453-1463. https://doi.org/10.1007/s11051-008-9533-6

HAVERKAMP, R. G., MARSHALL, A. T. \& VAN AGTERVELD, D. 2007. Pick your carats: nanoparticles of gold-silver-copper alloy produced in vivo. Journal of Nanoparticle Research, 9(4), 697-700. doi.10.1007/s11051-006-9198$\mathrm{y}$

HE, C., HU, Y., YIN, L., TANG, C., \& YIN, C. 2010. Effects of particle size and surface charge on cellular uptake and biodistribution of polymeric nanoparticles. Biomaterials, $31(13)$,

https://doi.org/10.1016/j.biomaterials.2010.01.065

HERNÁNDEZ-MUÑOZ, P., CERISUELO, J. P., DOMÍNGUEZ, I., LÓPEZCARBALLO, G., CATALÁ, R., \& GAVARA, R. 2019. Nanotechnology in Food 
Packaging. In Nanomaterials for Food Applications (pp. 205-232). Elsevier. https://doi.org/10.1016/B978-0-12-814130-4.00008-7

HERRMANN, J. M., DUCHAMP, C., KARKMAZ, M., HOAI, B. T., LACHHEB, H., PUZENAT, E., \& GUILLARD, C. 2007. Environmental green chemistry as defined by photocatalysis. Journal of Hazardous Materials, 146(3), 624-629. https://doi.org/10.1016/j.jhazmat.2007.04.095

HOSEINNEJAD, M., JAFARI, S. M., \& KATOUZIAN, I. 2018. Inorganic and metal nanoparticles and their antimicrobial activity in food packaging applications. Critical reviews in microbiology, 44(2), 161-181. https://doi.org/10.1080/1040841X.2017.1332001

HUANG, X., WU, H., LIAO, X., \& SHI, B. 2010. One-step, size-controlled synthesis of gold nanoparticles at room temperature using plant tannin. Green Chemistry, 12(3), 395-399. DOI:10,1039 / B918176H

IRAVANI S 2014 Bacteria in nanoparticle synthesis: current status and future prospects. Int Sch Res Notices. https://doi. org/10.1155/2014/359316

IRAVANI, S. 2011. Green synthesis of metal nanoparticles using plants. Green Chemistry, 13(10), 2638-2650.. DOI:10.1039 / C1GC15386B

JAFARIZADEH-MALMIRI, H., SAYYAR, Z., ANARJAN, N., \& BERENJIAN, A. 2019a. Nanobiotechnology in Food Packaging. In Nanobiotechnology in Food: Concepts, Applications and Perspectives (pp. 6979). Springer, Cham. https://doi.org/10.1007/978-3-030-05846-3_5

JAFARIZADEH-MALMIRI, H., SAYYAR, Z., ANARJAN, N., \& BERENJIAN, A. 2019b. Nano-additives for Food Industries. In Nanobiotechnology in Food: Concepts, Applications and Perspectives (pp. 4168). Springer, Cham. https://doi.org/10.1007/978-3-030-05846-3 4

JAFARIZADEH-MALMIRI, H., SAYYAR, Z., ANARJAN, N., \& BERENJIAN, A. 2019c. Nano-sensors in Food Nanobiotechnology. In Nanobiotechnology in Food: Concepts, Applications and Perspectives (pp. 8194). Springer, Cham. https://doi.org/10.1007/978-3-030-05846-3 6

JAIN, A., RANJAN, S., DASGUPTA, N., \& RAMALINGAM, C. 2018 Nanomaterials in food and agriculture: an overview on their safety concerns and regulatory issues. Critical reviews in food science and nutrition, 58(2), 297-317. https://doi.org/10.1080/10408398.2016.1160363

JAIN, A., RANJAN, S., DASGUPTA, N., RAMALINGAM, C. 2016 Nanomaterials in food and agriculture: an overview on their safety concerns and regulatory issues. Crit Rev Food Sci Nutr. doi:10.1080/ 10408398.2016.1160363 JAMDAGNI, P., KHATRI, P. \& RANA, J. S. 2018. Green synthesis of zinc oxide nanoparticles using flower extract of Nyctanthes arbor-tristis and thei antifungal activity. Journal of King Saud University-Science, 30(2), 168-175. https://doi.org/10.1016/j.jksus.2016.10.002

JIA, H., YANG, D., HAN, X., CAI, J., LIU, H., \& HE, W. 2016. Peroxidase-like activity of the $\mathrm{Co}_{3} \mathrm{O}_{4}$ nanoparticles used for biodetection and evaluation of antioxidant behavior. $\quad$ Nanoscale, 8(11), 5938-5945. doi.org/10.1039/C6NR00860G

KAPHLE, A., NAVYA, P. N., UMAPATHI, A., \& DAIMA, H. K. 2018 Nanomaterials for agriculture, food and environment: applications, toxicity and regulation. Environmental Chemistry Letters, 16(1), 43-58 https://doi.org/10.1007/s10311-017-0662-y

KASTHURI, J., VEERAPANDIAN, S., \& RAJENDIRAN, N. 2009. Biologica synthesis of silver and gold nanoparticles using apiin as reducing agent. Colloids $\begin{array}{lll}\text { and } & \text { Surfaces } & \text { B: } \quad \text { Biointerfaces, }\end{array}$ https://doi.org/10.1016/j.colsurfb.2008.09.021

KAYALVIZHI, T., RAVIKUMAR, S., \& VENKATACHALAM, P. 2016. Green synthesis of metallic silver nanoparticles using Curculigo orchioides rhizome extracts and evaluation of its antibacterial, larvicidal, and anticancer activity. Journal of Environmental Engineering, 142(9), C4016002.

KHAN, Z. U. H., KHAN, A., CHEN, Y., SHAH, N. S., MUHAMMAD, N., KHAN, A. U., ... AND QAISRANI, S. A. 2017. Biomedical applications of green synthesized Nobel metal nanoparticles. Journal of Photochemistry and $\begin{array}{lllll}\text { Photobiology } & B: & \text { Biology, } & 173, & 150-164\end{array}$ https://doi.org/10.1016/j.jphotobiol.2017.05.034

KHARAT, S. N., \& MENDHULKAR, V. D. 2016. Synthesis, characterization and studies on antioxidant activity of silver nanoparticles using Elephantopus scaber leaf extract. Materials Science and Engineering: C, 62, 719-724. https://doi.org/10.1016/j.msec.2016.02.024

KHARISSOVA, O. V., DIAS, H. R., KHARISOV, B. I., PEREZ, B. O. \& PEREZ, V. M. J. 2013. The greener synthesis of nanoparticles. Trends in biotechnology, 31(4), 240-248. https://doi.org/10.1016/j.tibtech.2013.01.003

KHATAMI, M., ALIJANI, H. Q. \& SHARIFI, I. 2018. Biosynthesis of bimetallic and core-shell nanoparticles: their biomedical applications-a review. IET nanobiotechnology, 12(7), 879-887. DOI: 10.1049 / iet-nbt.2017.0308

KHEDRI, B., SHAHANIPOUR, K., FATAHIAN, S., \& JAFARY, F. 2018 Preparation of chitosan-coated $\mathrm{Fe}_{3} \mathrm{O}_{4}$ nanoparticles and assessment of their effects on enzymatic antioxidant system as well as high-density lipoprotein/lowdensity lipoprotein lipoproteins on wistar rat. Biomedical and Biotechnology Research Journal (BBRJ), 2(1), 68. DOI: 10.4103/bbrj.bbrj_98_17

KHOSHNAMVAND, M., ASHTIANI, S., HUO, C., SAEB, S. P., \& LIU, J. 2019. Use of Alcea rosea leaf extract for biomimetic synthesis of gold nanoparticles with innate free radical scavenging and catalytic activities. Journal

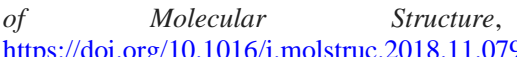

1179,

$749-755$

KIM, D. Y., SARATALE, R. G., SHINDE, S., SYED, A., AMEEN, F., \& GHODAKE, G. 2018. Green synthesis of silver nanoparticles using Laminaria japonica extract: Characterization and seedling growth assessment. Journal of Cleaner Production, 172

2910-2918

https://doi.org/10.1016/i.jclepro.2017.11.123

KIM, J. S., KUK, E., YU, K. N., KIM, J. H., PARK, S. J., LEE, H. J., ... \& KIM, Y. K. 2007. Antimicrobial effects of silver nanoparticles. Nanomedicine Nanotechnology, Biology and Medicine, 3(1), 95-101. https://doi. org/10.1016/j.nano.2006.12.001.

KING, T., OSMOND-MCLEOD, M. J., \& DUFFY, L. L. 2018. Nanotechnology in the food sector and potential applications for the poultry industry. Trends in Food Science \& Technology, 72, 62-73. https://doi.org/10.1016/j.tifs.2017.11.015 KOPERUNCHOLAN, M. 2015. Bioreduction of chloroauric acid (HAuCl4) for the synthesis of gold nanoparticles (GNPs): a special empathies of pharmacological activity. Int. J. Phytopharm., 5(4), 72-80.

KUMAR, D. L., \& SARKAR, P. 2018. Encapsulation of bioactive compounds using nanoemulsions. Environmental chemistry letters, 16(1), 59-70. https://doi.org/10.1007/s10311-017-0663-x

KUMAR, I., MONDAL, M., \& SAKTHIVEL, N. 2019a. Green synthesis of phytogenic nanoparticles. In Green Synthesis, Characterization and Applications of Nanoparticles (pp. 37-73). Elsevier. https://doi.org/10.1016/B978-0-08102579-6.00003-4

KUMAR, K. M., MANDAL, B. K., SINHA, M., \& KRISHNAKUMAR, V. 2012. Terminalia chebula mediated green and rapid synthesis of gold nanoparticles. Spectrochimica Acta Part A: Molecular and Biomolecular Spectroscopy, 86, 490-494. https://doi.org/10.1016/j.saa.2011.11.001

KUMAR, V., WADHWA, R., KUMAR, N., \& MAURYA, P. K. 2019b. A comparative study of chemically synthesized and Camellia sinensis leaf extractmediated silver nanoparticles. 3 Biotech, 9(1), 7. https://doi.org/10.1007/s13205018-1544-0

KUSWANDI, B., \& MORADI, M. 2019. Improvement of Food Packaging Based on Functional Nanomaterial. In Nanotechnology: Applications in Energy, Drug and Food (pp. 309-344). Springer, Cham. https://doi.org/10.1007/978-3-31999602-8_16

LAURENT, S., FORGE, D., PORT, M., ROCH, A., ROBIC, C., VANDER ELST, L., \& MULLER, R. N. 2008. Magnetic iron oxide nanoparticles: synthesis, stabilization, vectorization, physicochemical characterizations, and biological applications. Chemical reviews, 108(6), 2064-2110. https://doi.org/10.1021/cr068 445e.

LEE, K. H., LEE, J. S., KIM, E. S., \& LEE, H. G. 2019. Preparation, characterization, and food application of rosemary extract-loaded antimicrobial $\begin{array}{llll}\text { nanoparticle dispersions. } & L W T, & 101, & 138-144\end{array}$ https://doi.org/10.1016/j.1wt.2018.10.072

LEE, S. W., MAO, C., FLYNN, C. E. \& BELCHER, A. M. 2002. Ordering of quantum dots using genetically engineered viruses. Science, 296(5569), 892-895. DOI: $10.1126 /$ science. 1068054

LEE, S. Y., KRISHNAMURTHY, S., CHO, C. W., \& YUN, Y. S. 2016 Biosynthesis of gold nanoparticles using Ocimum sanctum extracts by solvents with different polarity. ACS Sustainable Chemistry \& Engineering, 4(5), 26512659. DOI: $10.1021 /$ acssuschemeng.6b00161

LI, H., WANG, T., WANG, Y., WANG, S., SU, P., \& YANG, Y. 2018. Intrinsic triple-enzyme mimetic activity of $\mathrm{V}_{6} \mathrm{O}_{13}$ nanotextiles: mechanism investigation and colorimetric and fluorescent detections. Industrial \& Engineering Chemistry Research, 57 (6), 2416-2425. https://doi.10.1021/acs.iecr.7b04821

LI, S., SHEN, Y., XIE, A., YU, X., QIU, L., ZHANG, L., \& ZHANG, Q. 2007. Green synthesis of silver nanoparticles using Capsicum annuum L. extract. Green Chemistry, 9(8), 852-858. DOI:10.1039 / B615357G

LIAO, H., HU, L., ZHANG, Y., YU, X., LIU, Y., \& LI, R. 2018. A highly selective colorimetric sulfide assay based on the inhibition of the peroxidase-like activity of copper nanoclusters. Microchimica Acta, 185(2), 143. https://doi.org/10.1007/s00604-018-2701-1

LIN, L., WANG, W., HUANG, J., LI, Q., SUN, D., YANG, X., ... \& WANG, Y 2010. Nature factory of silver nanowires: Plant-mediated synthesis using broth of Cassia fistula leaf. Chemical Engineering Journal, 162(2), 852-858. https://doi.org/10.1016/j.cej.2010.06.023

LIN, Z., WU, J., XUE, R. \& YANG, Y. 2005. Spectroscopic characterization of $\mathrm{Au}^{3+}$ biosorption by waste biomass of Saccharomyces cerevisiae. Spectrochimica Acta Part A: Molecular and Biomolecular Spectroscopy, 61(4), 761-765. https://doi.org/10.1016/j.saa.2004.03.029

LIU, F., ZHANG, S., LI, J., MCCLEMENTS, D. J., \& LIU, X. 2018. Recent development of lactoferrin-based vehicles for the delivery of bioactive compounds: Complexes, emulsions, and nanoparticles. Trends in Food Science \& Technology. https://doi.org/10.1016/j.tifs.2018.06.013

LUKMAN, A. I., GONG, B., MARJO, C. E., ROESSNER, U., \& HARRIS, A. T. 2011. Facile synthesis, stabilization, and anti-bacterial performance of discrete Ag nanoparticles using Medicago sativa seed exudates. Journal of colloid and interface science, 353(2), 433-444. https://doi.org/10.1016/j.jcis.2010.09.088 
MAKAROV, V. V., LOVE, A. J., SINITSYNA, O. V., MAKAROVA, S. S., YAMINSKY, I. V., TALIANSKY, M. E., \& KALININA, N. O. (2014). "Green" nanotechnologies: synthesis of metal nanoparticles using plants. Acta Naturae, 6(1 (20). 35-44.

MANIKANDAN, V., JAYANTHI, P., PRIYADHARSAN, A. VIJAYAPRATHAP, E., ANBARASAN, P. M., \& VELMURUGAN, P. 2019. Green synthesis of $\mathrm{pH}$-responsive $\mathrm{Al} 2 \mathrm{O} 3$ nanoparticles: Application to rapid removal of nitrate ions with enhanced antibacterial activity. Journal of Photochemistry and Photobiology A: Chemistry, 371, 205-215. https://doi.org/10.1016/j.jphotochem.2018.11.009

MATTAROZZI, M., BIANCHI, F., MAFFINI, M., VESCOVI, F. CATELLANI, D., SUMAN, M., \& CARERI, M. 2019. ESEM-EDS-based analytical approach to assess nanoparticles for food safety and environmental control. Talanta, 196, 429-435. https://doi.org/10.1016/j.talanta.2018.12.093 MISHRA, P. M., SUNDARAY, L., NAIK, G. K., \& PARIDA, K. M. 2014 Biomimetic synthesis of silver nanoparticles by aqueous extract of Cinnamomum tamala leaves: optimization of process variables. Nanoscience and Nanotechnology Letters, 6(5), 409-414. https://doi.org/10.1166/nnl.2014.1771 MISHRA, P., RAY, S., SINHA, S., DAS, B., KHAN, M. I., BEHERA, S. K., \& MISHRA, A. 2016. Facile bio-synthesis of gold nanoparticles by using extract of Hibiscus sabdariffa and evaluation of its cytotoxicity against U87 glioblastoma cells under hyperglycemic condition. Biochemical engineering journal, 105, 264-272. https://doi.org/10.1016/j.bej.2015.09.021

MUTHUKUMAR, T., SAMBANDAM, B., ARAVINTHAN, A., SASTRY, T P., \& KIM, J. H. 2016. Green synthesis of gold nanoparticles and their enhanced synergistic antitumor activity using HepG2 and MCF7 cells and its antibacterial effects. Process Biochemistry, 51(3), 384-391. https://doi.org/10.1016/j.procbio.2015.12.017

NARAGINTI, S., KUMARI, P. L., DAS, R. K., SIVAKUMAR, A., PATIL, S. H., \& ANDHALKAR, V. V. 2016. Amelioration of excision wounds by topical application of green synthesized, formulated silver and gold nanoparticles in albino Wistar rats. Materials Science and Engineering: C, 62, 293-300. https://doi.org/10.1016/j.msec.2016.01.069

NARAYANAN, K. B. \& SAKTHIVEL, N. 2011a. Extracellular synthesis of silver nanoparticles using the leaf extract of Coleus amboinicus Lour. Materials Research Bulletin, $46(10)$

1708-1713

https://doi.org/10.1016/j.materresbull.2011.05.041

NARAYANAN, K. B. \& SAKTHIVEL, N. 2011b. Facile green synthesis of gold nanostructures by NADPH-dependent enzyme from the extract of Sclerotium rolfsii. Colloids and Surfaces A: Physicochemical and Engineering Aspects, 380(1-3), 156-161. https://doi.org/10.1016/j.colsurfa.2011.02.042 NASROLLAHZADEH, M., SAJADI, S. M., \& KHALAJ, M. 2014. Green synthesis of copper nanoparticles using aqueous extract of the leaves of Euphorbia esula L and their catalytic activity for ligand-free Ullmann-coupling reaction and reduction of 4-nitrophenol. RSC Advances, 4(88), 47313-47318. DOI:10,1039 / C4RA08863H

NAVYA, P. N., \& DAIMA, H. K. 2016. Rational engineering of physicochemical properties of nanomaterials for biomedical applications with nanotoxicological perspectives. Nano Convergence, 3(1), 1-14. https://doi.org/10.1186/s40580-016-0064-Z

NAYAK, S., SAJANKILA, S. P., \& RAO, C. V. 2018. Green synthesis of gold nanoparticles from banana pith extract and its evaluation of antibacterial activity and catalytic reduction of malachite green dye. The Journal of Microbiology, Biotechnology and Food Sciences, 7(6), 641. doi: 10.15414/jmbfs.2018.7.6.641645

NUNE, S. K., CHANDA, N., SHUKLA, R., KATTI, K., KULKARNI, R. R. THILAKAVATHY, S., ... \& KATTI, K. V. 2009. Green nanotechnology from tea: phytochemicals in tea as building blocks for production of biocompatible gold nanoparticles. Journal of materials chemistry, 19(19), 2912-2920.

NURFATIHAH, Z. \& SIDDIQUEE, S. 2019. Nanotechnology: Recent Trends in Food Safety, Quality and Market Analysis. In Nanotechnology: Applications in Energy, Drug and Food (pp. 283-293). Springer, Cham. https://doi.org/10.1007/978-3-319-99602-8_14

OH, J. K., LIU, S., JONES, M., YEGIN, Y., HAO, L., TOLEN, T. N., ... \& CISNEROS-ZEVALLOS, L. 2019. Modification of aluminum surfaces with superhydrophobic nanotextures for enhanced food safety and hygiene. Food Control, 96, 463-469. https://doi.org/10.1016/j.foodcont.2018.10.005

OSKAM, G. 2006. Metal oxide nanoparticles: synthesis, characterization and application. Journal of sol-gel science and technology, 37(3), 161-164. https://doi.org/10.1007/s10971-005-6621-2

PAL, G., RAI, P. \& PANDEY, A. 2019. Green synthesis of nanoparticles: A greener approach for a cleaner future. In Green Synthesis, Characterization and Applications of Nanoparticles (pp. 1-26). Elsevier. https://doi.org/10.1016/B9780-08-102579-6.00001-0

PANTIDOS, N. \& HORSFALL, L. E. 2014. Biological synthesis of metallic nanoparticles by bacteria, fungi and plants. Journal of Nanomedicine and Nanotechnology, 5(5), 1. http://dx.doi.org/10.4172/2157-7439.1000233

PATEL, A., PATRA, F., SHAH, N., \& KHEDKAR, C. 2018. Application of nanotechnology in the food industry: present status and future prospects. In
Impact of Nanoscience in the Food Industry (pp. 1-27) https://doi.org/10.1016/B978-0-12-811441-4.00001-7

PATRA, S., MUKHERJEE, S., BARUI, A. K., GANGULY, A., SREEDHAR, B., \& PATRA, C. R. 2015. Green synthesis, characterization of gold and silver nanoparticles and their potential application for cancer therapeutics. Materials $\begin{array}{lllll}\text { Science } & \text { and } & \text { Engineering: } & \text { 298-309. }\end{array}$ https://doi.org/10.1016/j.msec.2015.04.048

PAUL, S. K., DUTTA, H., SARKAR, S., SETHI, L. N., \& GHOSH, S. K. 2019. Nanosized Zinc Oxide: Super-Functionalities, Present Scenario of Application, Safety Issues, and Future Prospects in Food Processing and Allied Industries. Food Reviews International,

https://doi.org/10.1080/87559129.2019.1573828

PONCE, A. G., AYALA-ZAVALA, J. F., MARCOVICH, N. E., VÁZQUEZ, F. J., \& ANSORENA, M. R. 2018. Nanotechnology Trends in the Food Industry: Recent Developments, Risks, and Regulation. In Impact of Nanoscience in the Food Industry (pp. 113-141). https://doi.org/10.1016/B978-0-12-8114414.00005-4

PRAJITHA, N., ATHIRA, S. S., \& MOHANAN, P. V. 2019. Bio-interactions and risks of engineered nanoparticles. Environmental research https://doi.org/10.1016/i.envres.2019.02.003

PRASANNA, S. S., BALAJI, K., PANDEY, S. \& RANA, S. 2019. Metal Oxide Based Nanomaterials and Their Polymer Nanocomposites. In Nanomaterials and Polymer Nanocomposites (pp. 123-144). Elsevier. https://doi.org/10.1016/B978 0-12-814615-6.00004-7

RAGAVAN, K. V., \& NEETHIRAJAN, S. 2019. Nanoparticles as Biosensors for Food Quality and Safety Assessment. In Nanomaterials for Food Applications (pp. 147-202). Elsevier. https://doi.org/10.1016/B978-0-12-8141304.00007-5

RAJESHKUMAR S, BHARATH L. V. 2017 Mechanism of plant-mediated synthesis of silver nanoparticles-a review on biomolecules involved, characterisation and antibacterial activity. Chem-Biol Interact 273:219-227. https://doi.org/10.1016/j.cbi.2017.06.019

RAMESH, P. S., KOKILA, T., \& GEETHA, D. 2015. Plant mediated green synthesis and antibacterial activity of silver nanoparticles using Emblica officinalis fruit extract. Spectrochimica Acta Part A: Molecular and Biomolecular Spectroscopy, $\quad 142, \quad 339-343$. https://doi.org/10.1016/j.saa.2015.01.062

RANJAN, S., DASGUPTA, N., CHAKRABORTY, A. R., SAMUEL, S. M., RAMALINGAM, C., SHANKER, R., \& KUMAR, A. 2014. Nanoscience and nanotechnologies in food industries: opportunities and research trends. Journal of Nanoparticle Research, 16(6), 2464. https://doi.org/10.1007/s11051-014-2464-5 RANJAN, S., DASGUPTA, N., SINGH, S., \& GANDHI, M. 2018. Toxicity and regulations of food nanomaterials. Environmental Chemistry Letters, 1-16. https://doi.org/10.1007/s10311-018-00851-z

RAO, N. H., LAKSHMIDEVI, N., PAMMI, S. V. N., KOLLU, P. GANAPATY, S., \& LAKSHMI, P. 2016. Green synthesis of silver nanoparticles using methanolic root extracts of Diospyros paniculata and their antimicrobial activities. Materials Science and Engineering: C, 62, 553-557. https://doi.org/10.1016/j.msec.2016.01.072

RAUTELA, A., RANI, J., \& DAS, M. D. 2019. Green synthesis of silver nanoparticles from Tectona grandis seeds extract: characterization and mechanism of antimicrobial action on different microorganisms. Journal of Analytical Science and Technology, 10(1), 5. https://doi.org/10.1186/s40543-0180163-Z

RAVEENDRAN, P., FU, J., \& WALLEN, S. L. 2003. Completely "green" synthesis and stabilization of metal nanoparticles. Journal of the American Chemical Society, 125(46), 13940-13941. DOI: 10.1021 / ja029267j

RAVICHANDRAN, R. 2010. Nanotechnology applications in food and food processing: innovative green approaches, opportunities and uncertainties for global market. International Journal of Green Nanotechnology: Physics and Chemistry, 1(2), P72-P96. https://doi.org/10.1080/19430871003684440

ROMAN'KO, M. Y. 2017. Biochemical markers of safety of nano-particles of metals on the model of isolated subcultural fractions of eukaryotes. Regulatory Mechanisms in Biosystems, 8(4), 564-568. https://doi.org/10.15421/021787 ROSELINE, T. A., MURUGAN, M., SUDHAKAR, M. P. \& ARUNKUMAR, K. 2019. Nanopesticidal potential of silver nanocomposites synthesized from the aqueous extracts of red seaweeds. Environmental Technology and Innovation, 13 , 82-93. https://doi.org/10.1016/j.eti.2018.10.005

SANGEETHA, G., RAJESHWARI, S., \& VENCKATESH, R. 2011. Green synthesis of zinc oxide nanoparticles by aloe barbadensis miller leaf extract: Structure and optical properties. Materials Research Bulletin, 46(12), 2560-2566. https://doi.org/10.1016/j.materresbull.2011.07.046

SANJAY, S. S. 2019. Safe nano is green nano. In Green Synthesis, Characterization and Applications of Nanoparticles (pp. 27-36). Elsevier https://doi.org/10.1016/B978-0-08-102579-6.00002-2

SANTHOSHKUMAR, J., RAJESHKUMAR, S., \& KUMAR, S. V. 2017. Phytoassisted synthesis, characterization and applications of gold nanoparticles-A review. Biochemistry and biophysics reports, 11, 46-57. https://doi.org/10.1016/j.bbrep.2017.06.004 
SARAVANAKUMAR, K., CHELLIAH, R., SHANMUGAM, S. VARUKATTU, N. B., OH, D. H., KATHIRESAN, K., \& WANG, M. H. 2018. Green synthesis and characterization of biologically active nanosilver from seed extract of Gardenia jasminoides Ellis. Journal of Photochemistry and Photobiology B: Biology. https://doi.org/10.1016/j.jphotobiol.2018.05.032

SARDAR, M. \& MAZUMDER, J. A. 2019. Biomolecules Assisted Synthesis of Metal Nanoparticles. In Environmental Nanotechnology (pp. 1-23). Springer, Cham. https://doi.org/10.1007/978-3-319-98708-8_1

SATHISHKUMAR, M., SNEHA, K., \& YUN, Y. S. 2010. Immobilization of silver nanoparticles synthesized using Curcuma longa tuber powder and extract on cotton cloth for bactericidal activity. Bioresource technology, 101(20), 79587965. https://doi.org/10.1016/j.biortech.2010.05.051

SELVAKANNAN, P. R., MANDAL, S., PHADTARE, S., GOLE, A., PASRICHA, R., ADYANTHAYA, S. D., \& SASTRY, M. 2004. Waterdispersible tryptophan-protected gold nanoparticles prepared by the spontaneous reduction of aqueous chloroaurate ions by the amino acid. Journal of colloid and interface science, 269(1), 97-102. https://doi.org/10.1016/S0021-9797(03)00616-

SENGANI, M., GRUMEZESCU, A. M., \& RAJESWARI, V. D. 2017. Recen trends and methodologies in gold nanoparticle synthesis-A prospective review on drug delivery aspect. OpenNano, 2, 37-46. https://doi.org/10.1016/j.onano.2017.07.001

SHAHVERDI, A. R., MINAEIAN, S., SHAHVERDI, H. R., JAMALIFAR, H. \& NOHI, A. A. 2007. Rapid synthesis of silver nanoparticles using culture supernatants of Enterobacteria: a novel biological approach. Process Biochemistry, 42(5), 919-923. https://doi.org/10.1016/j.procbio.2007.02.005

SHANKAR, S. S., AHMAD, A., \& SASTRY, M. 2003. Geranium leaf assisted biosynthesis of silver nanoparticles. Biotechnology progress, 19(6), 1627-1631. https://doi.org/10.1021/bp034070w

SHANKAR, S. S., RAI, A., AHMAD, A., \& SASTRY, M. 2004. Rapid synthesis of $\mathrm{Au}, \mathrm{Ag}$, and bimetallic $\mathrm{Au}$ core- $\mathrm{Ag}$ shell nanoparticles using Neem (Azadirachta indica) leaf broth. Journal of colloid and interface science, 275(2), 496-502. https://doi.org/10.1016/j.jcis.2004.03.003

SHENTON, W., DOUGLAS, T., YOUNG, M., STUBBS, G. \& MANN, S. 1999 Inorganic-organic nanotube composites from template mineralization of tobacco mosaic virus. Advanced Materials, 11(3), 253-256. https://doi.org/10.1002/(SICI)1521-4095(199903)11:3<253::AID-

ADMA253>3.0.CO;2-7

SHUKLA, V. K., YADAV, R. S., YADAV, P., \& PANDEY, A. C. 2012. Green synthesis of nanosilver as a sensor for detection of hydrogen peroxide in water. Journal of hazardous materials, 213, 161-166. https://doi.org/10.1016/j.jhazmat.2012.01.071

SIMS, C. M., HANNA, S. K., HELLER, D. A., HOROSZKO, C. P., JOHNSON, M. E., BUSTOS, A.R. M., REIPA, V., RILEY, K. R., \& NELSON, B. C. 2017 Redox-active nanomaterials for nanomedicine applications. Nanoscale, 9(40), 15226-15251. https://doi.org/10.1039/C7NR05429G

SINGH, H. 2016. Nanotechnology applications in functional foods; opportunities and challenges. Preventive nutrition and food science, 21(1), 1-8 http://dx.doi.org/10.3746

SINGH, J., VISHWAKARMA, K., RAMAWAT, N., RAI, P., SINGH, V. K. MISHRA, R. K., ... AND SHARMA, S. 2019. Nanomaterials and microbes' interactions: a contemporary overview. 3 Biotech, 9(3), 68. https://doi.org/10.1007/s13205-019-1576-0

SNEHA, H. P., BEULAH, K. C., \& MURTHY, P. S. 2019. Enzyme Immobilization Methods and Applications in the Food Industry. In Enzymes in Food Biotechnology (pp. 645-658). Academic Press. https://doi.org/10.1016/B978-0-12-813280-7.00037-2

SONAWANE, S. K., PATIL, S. P., \& ARYA, S. S. 2018. Nanotechnology enrolment in food and food safety. Journal of Microbiology, Biotechnology \& Food Sciences, 8(3). 10.15414 / jmbfs. 2018-19.8.3.893-900

SONG, J. Y., KWON, E. Y., \& KIM, B. S. 2010. Biological synthesis of platinum nanoparticles using Diopyros kaki leaf extract. Bioprocess and biosystems engineering, 33(1), 159. https://doi.org/10.1007/s00449-009-0373-2

SONG, Y., ZHAO, M., LI, H., WANG, X., CHENG, Y., DING, L., FAN, S., \& CHEN, S. 2018. Facile preparation of urchin-like $\mathrm{NiCo}_{2} \mathrm{O}_{4}$ microspheres as oxidase mimetic for colormetric assay of hydroquinone. Sensors and Actuators B: Chemical, 255, 1927-1936. https://doi.org/10.1016/.snb.2017.08.204 SPIVAK, M. Y., BUBNOV, R. V., YEMETS, I. M., LAZARENKO, L. M., TYMOSHOK, N. O., \& ULBERG, Z. R. (2013). Development and testing of gold nanoparticles for drug delivery and treatment of heart failure: a theranostic potential for PPP cardiology. Epma Journal, 4(1), 20. doi: 10.1186/1878-5085-420.

SU, X. Y., LIU, P. D., WU, H., \& GU, N. 2014. Enhancement of radiosensitization by metal-based nanoparticles in cancer radiation therapy. Cancer biology \& medicine, 11(2), 86.-91. https://doi.org/10.7497/j.issn.20953941.2014.02.003.

SUJATHA, J., ASOKAN, S., \& RAJESHKUMAR, S. 2018. Antidermatophytic activity of green synthesised zinc oxide nanoparticles using Cassia alata LEAVES. The Journal of Microbiology, Biotechnology and Food Sciences, 7(4), 348. doi: 10.15414/jmbfs.2018.7.4.348-352
SUMITHA, S., VASANTHI, S., SHALINI, S., CHINNI, S. V., GOPINATH, S C. B., KATHIRESAN, S., ... \& RAVICHANDRAN, V. 2019. Durio zibethinus rind extract mediated green synthesis of silver nanoparticles: Characterization and biomedical applications. Pharmacognosy Magazine, 15(60), 52-58. . DOI 10,4103 / pm.pm 40018

THAKUR, S., THAKUR, S. \& KUMAR, R. 2018. Bio-nanotechnology and its role in agriculture and food industry. $J$ Mol Genet Med, 12(324), 1747-0862. DOI: $10.4172 / 1747-0862.1000324$

THOMAS, B., VITHIYA, B., PRASAD, T., MOHAMED, S. B., MAGDALANE, C. M., KAVIYARASU, K. \& MAAZA, M. 2019. Antioxidant and Photocatalytic Activity of Aqueous Leaf Extract Mediated Green Synthesis of Silver Nanoparticles Using Passiflora edulis f. flavicarpa. Journal of nanoscience and nanotechnology, 19(5), 2640-2648. https://doi.org/10.1166/jnn.2019.16025

THORLEY, A. J., \& TETLEY, T. D. 2013. New perspectives in nanomedicine. $\begin{array}{llll}\text { Pharmacology \& therapeutics, } 140(2), & 176-185\end{array}$ https://doi.org/10.1016/j.pharmthera.2013.06.008

TSEKHMISTRENKO O.S, TSEKHMISTRENKO S.I, BITYUTSKYY V.S MELNICHENKO O.M, OLESHKO O.A. 2018a. Biomimetic and antioxidant activity of nano-crystalline cerium dioxide. Svit medytsyny ta biolohii, 63 (1), 196-201. (In Ukrainian). https://doi.10.267254 / 2079-8334-2018-1-63-192-196 TSEKHMISTRENKO, S. I., BITYUTSKYY, V. S., TSEKHMISTRENKO, O. S., POLISHCHUK, V. M., POLISHCHUK, S. A., PONOMARENKO, N. V., .. \& SPIVAK, M. Y. 2018b. Enzyme-like activity of nanomaterials. Regulatory Mechanisms in Biosystems, 9(3), 469-476. https://doi.org/10.15421/021870

UMMI, A. S., \& SIDDIQUEE, S. 2019. Nanotechnology Applications in Food: Opportunities and Challenges in Food Industry. In Nanotechnology: Applications in Energy, Drug and Food (pp. 295-308). Springer, Cham. https://doi.org/10.1007/978-3-319-99602-8_15

VENNILA, K., CHITRA, L., BALAGURUNATHAN, R., \& PALVANNAN, T. 2018. Comparison of biological activities of selenium and silver nanoparticles attached with bioactive phytoconstituents: green synthesized using Spermacoce hispida extract. Advances in Natural Sciences: Nanoscience and Nanotechnology, 9(1), 015005. https://doi.org/10.1088/2043-6254/aa9f4d

WANG, K., SONG, J., DUAN, X., MU, J., \& WANG, Y. 2017. Perovskite $\mathrm{LaCoO}_{3}$ nanoparticles as enzyme mimetics: their catalytic properties, mechanism and application in dopamine biosensing. New Journal of Chemistry, 41(16), 8554-8560. DOI: $10.1039 / \mathrm{C} 7 \mathrm{NJ} 01177 \mathrm{~F}$

WANG, Q., ZHANG, L., SHANG, C., ZHANG, Z., \& DONG, S. 2016. Tripleenzyme mimetic activity of nickel-palladium hollow nanoparticles and thei application in colorimetric biosensing of glucose. Chemical Communications, 52(31), 5410-5413. https://doi.org/10.1039/C6CC00194G

WANG, T., JIN, X., CHEN, Z., MEGHARAJ, M., \& NAIDU, R. 2014. Green synthesis of $\mathrm{Fe}$ nanoparticles using eucalyptus leaf extracts for treatment of eutrophic wastewater. Science of the total environment, 466, 210-213. https://doi.org/10.1016/j.scitotenv.2013.07.022

WILLETT, R. L., BALDWIN, K. W., WEST, K. W., \& PFEIFFER, L. N. 2005. Differential adhesion of amino acids to inorganic surfaces. Proceedings of the National Academy of Sciences, 102(22), 7817-7822. https://doi.org/10.1073/pnas.0408565102

YADI, M., MOSTAFAVI, E., SALEH, B., DAVARAN, S., ALIYEVA, I., KHALILOV, R., ... \& MILANI, M. 2018. Current developments in green synthesis of metallic nanoparticles using plant extracts: a review. Artificial cells, nanomedicine, and biotechnology,

https://doi.org/10.1080/21691401.2018.1492931

YAN, X., SONG, Y., WU, X., ZHU, C., SU, X., DU, D., \& LIN, Y. 2017. Oxidase-mimicking activity of ultrathin $\mathrm{MnO}_{2}$ nanosheets in colorimetric assay of acetylcholinesterase activity. Nanoscale, 9(6), 2317-2323. DOI:10.1039/C6NR08473G

YONG, P., ROWSON, N. A., FARR, J. P. G., HARRIS, I. R. \& MACASKIE, L. E. 2002. Bioaccumulation of palladium by Desulfovibrio desulfuricans. Journal of Chemical Technology and Biotechnology, 77(5), 593-601. https://doi.org/10.1002/jctb.606

ZHAO, J., DONG, W., ZHANG, X., CHAI, H., \& HUANG, Y. 2018 FeNPs@ $\mathrm{Co}_{3} \mathrm{O}_{4}$ hollow nanocages hybrids as effective peroxidase mimics for glucose biosensing. Sensors and Actuators B: Chemical. https://doi.org/10.1016/j.snb.2018.02.151

ZHIHAREV, I. V., LJASHENKO, V. I. 2007. Nanotehnologii v mire i Ukraine: problemy i perspektivy . Ekonomichnij visnik Donbasu. 1, 117-145. (in Russian). 